\title{
Huntington's Disease, Critical Illness Insurance and Life Insurance
}

\author{
CRISTINA GUTIÉRREZ and ANGUS MACDONALD
}

Gutiérrez C. and Macdonald A. Huntington's disease, critical illness insurance and life insurance. Scand. Actuarial J. 2004; 4: 279-313.

We describe briefly a model of Huntington's disease (HD), a highly penetrant, dominantly inherited, fatal neurological disorder. Although it is a single-gene disorder, mutations are variable in their effects, depending on the number of times that the CAG trinucleotide is repeated in a certain region of the HD gene. The model covers: (a) rates of onset, depending on CAG repeat length as well as age; (b) post-onset rates of mortality; and (c) the distribution of CAG repeat lengths in the population. Using these, we study the critical illness and life insurance markets. We calculate premiums based on genetic test results that disclose the CAG repeat length, or more simply on a family history of HD. These vary widely with age and policy term; some are exceptionally high, but in a large number of cases cover could be offered within normal underwriting limits. We then consider the possible costs of adverse selection, in terms of increased premiums, under various possible moratoria on the use of genetic information, including family history. These are uniformly very small, because of the rarity of HD, but do show that the costs would be much larger in relative terms if family history could not be used in underwriting. We point out some difficulties involved in applying a moratorium that recognises simply a dichotomy between 'carriers' and 'non-carriers' of any mutation in a gene when these mutations are, in fact, very variable in their effects. These complexities suggest that restrictions on the disclosure, rather than on the use, of genetic information, if it became established as a principle, could deprive insurers of information needed for risk management even if not used in underwriting. Key words: Critical illness insurance, family history, genetic tests, Huntington's disease, life insurance, moratorium, underwriting.

\section{INTRODUCTION}

Huntington's disease (HD) is a dominantly inherited, fatal brain disease, caused by mutations in the HD gene. It has an extensive epidemiological literature, because it had been studied on the basis of family history for a long time before genetic tests were developed. What modern molecular genetics has revealed, however, is that the causative mutations are variable in their structure and in their effects. A certain region of the gene contains, in sequence, a variable number of CAG trinucleotides, 
each encoding the amino acid glutamine. This sequence is unstable and liable to expand in successive generations. The vast majority of people have fewer than 35 CAG repeats, and are not at risk of HD. If there are 40 or more CAG repeats, onset of HD is practically certain. An 'intermediate allele' with 36-39 CAG repeats presents some risk of HD, but onset is not certain. Harper (1996) is the major reference work on HD.

Gutiérrez \& Macdonald (2002) surveyed the literature of HD and proposed models for the features of HD most relevant for insurance applications:

(a) the rate of onset as a function of age and CAG repeat length;

(b) post-onset survival rates; and

(c) the distribution of CAG repeat lengths in the population.

In this paper, we introduce these models briefly and apply them to critical illness (CI) and life insurance. For brevity, we refer the reader to Macdonald (2003b), or to a textbook such as Strachan \& Read (1999) for the genetical background and terminology.

CI insurance (also known as dread disease or trauma insurance) is, in principle, the easiest contract to model, because payment is related to onset, and rates of onset are age-dependent, so a Markov model can be used to calculate premiums and reserves. We describe such a model in Section 3. However, onset of HD does not necessarily trigger a CI claim, as the criteria for disability might be reached only after the disease has progressed to a later stage. We allow for this with an accelerated lifetime model based on the post-onset mortality. Then, in Section 4 we obtain CI insurance premiums allowing for a genetic test that reveals the number of CAG repeats, or a family history of HD; and in Section 5, we model the possible costs of adverse selection in the CI insurance market, under various moratoria on the use of genetic test results or family history.

In Section 6 we propose a semi-Markov model for the life insurance market, and we consider premium ratings and adverse selection costs in Sections 7 and 8, respectively. Our conclusions are in Section 9.

\section{THE MODEL OF HUNTINGTON'S DISEASE}

The model of onset is based on Brinkman et al. (1997), who studied a cohort of 1,049 affected and asymptomatic at-risk persons, from many different countries. The number of CAG repeats was established for each person. For each number in the range 39-50, the cumulative probability of surviving without $\mathrm{HD}$, at roughly quinquennial ages, was estimated by Kaplan-Meier methods, and 95\% confidence intervals were also given. 'Age at onset' was defined as "... the first time a patient has either neurological or psychiatric symptoms that represented a permanent change from the normal state." These data for 40-50 CAG repeats are shown in Figs. 1 and 2 in the form of penetrance estimates at selected ages ('penetrance by age $x$ ' is the probability that HD has appeared by age $x$, all other decrements being absent): 

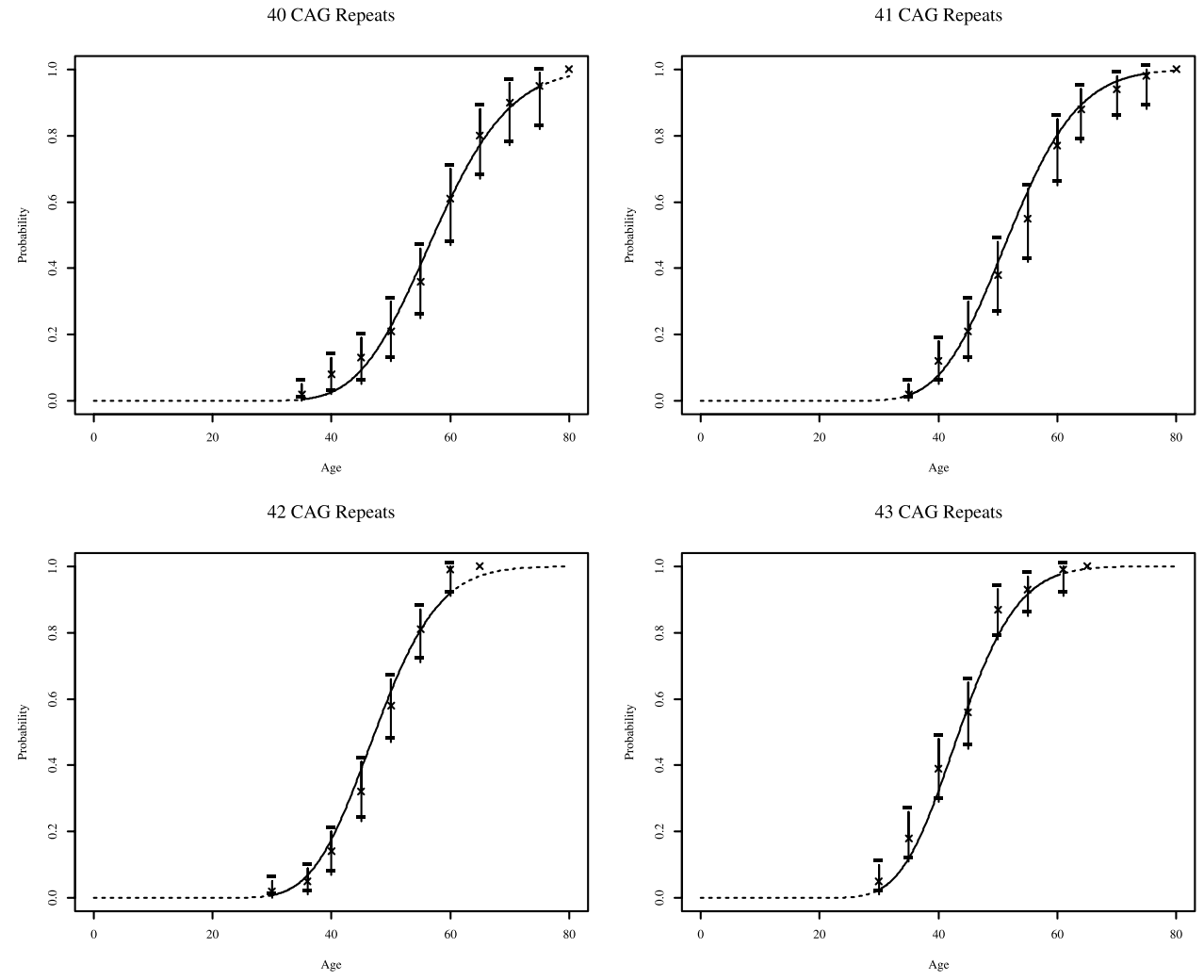

44 CAG Repeats

45 CAG Repeats
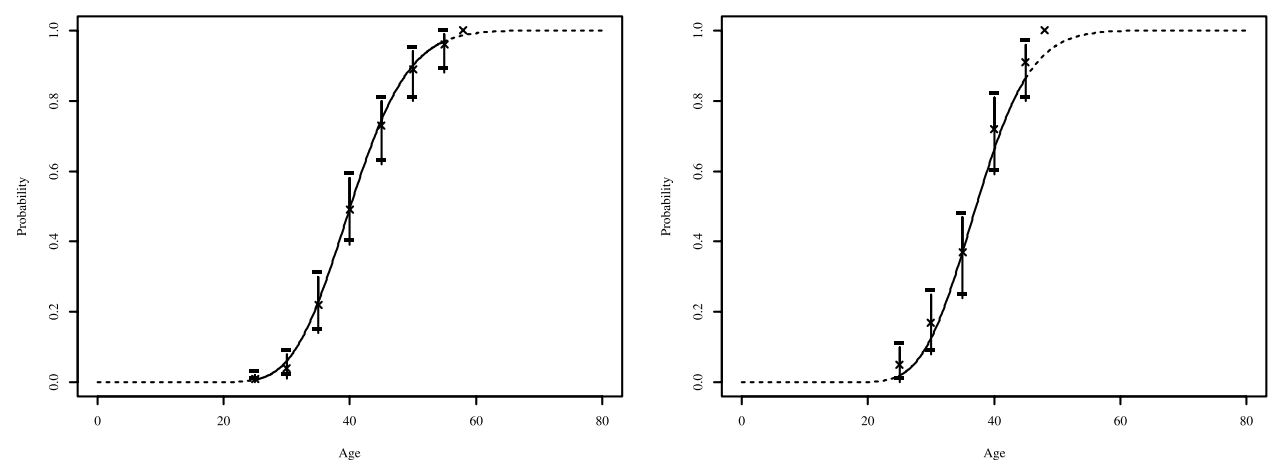

Fig. 1. Penetrance estimates of onset of HD with 40-45 CAG repeats (crosses) and $95 \%$ confidence intervals, from Brinkman et al. (1997). Also shown are the fitted penetrance curves from the model.

Also shown are the penetrance curves of the following model:

Penetrance at age $x=\frac{\theta^{\alpha}}{\Gamma(\alpha)} \int_{0}^{x} t^{\alpha-1} \exp (-t \theta) d t$ 

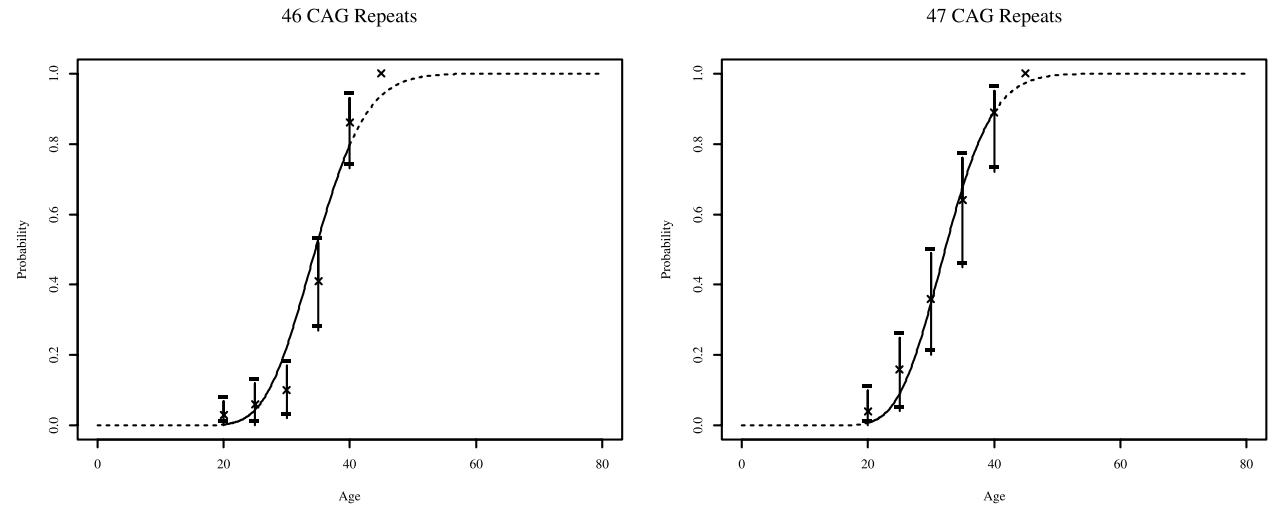

48 CAG Repeats

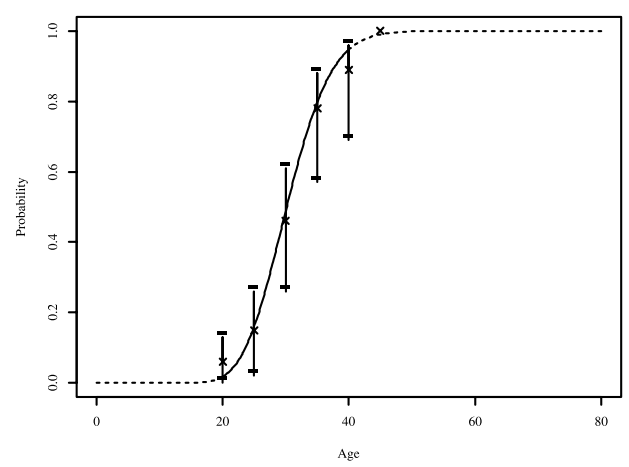

49 CAG Repeats

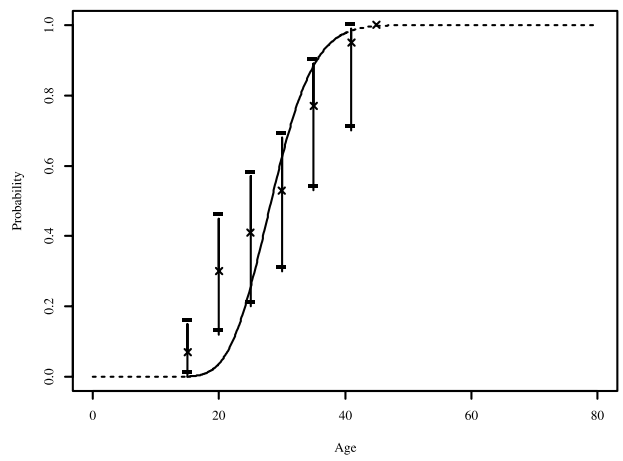

50 CAG Repeats

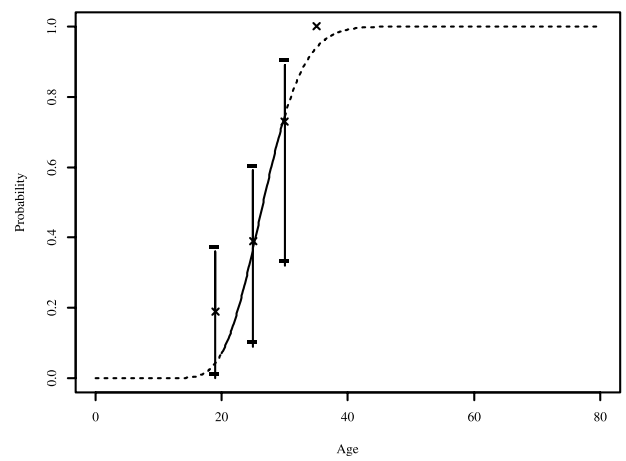

Fig. 2. Penetrance estimates of onset of HD with 46-50 CAG repeats (crosses) and 95\% confidence intervals, from Brinkman et al. (1997). Also shown are the fitted penetrance curves from the model.

where $R$ is the number of CAG repeats, $\alpha=48.1685-0.376508 R, \theta=0.051744 R-$ 1.49681 and $x \geqslant 0$. Brinkman et al. (1997) did not provide penetrances for fewer than 39 CAG repeats, but the model allows for reasonable extrapolation down to $36 \mathrm{CAG}$ repeats, as shown in Fig. 3. 


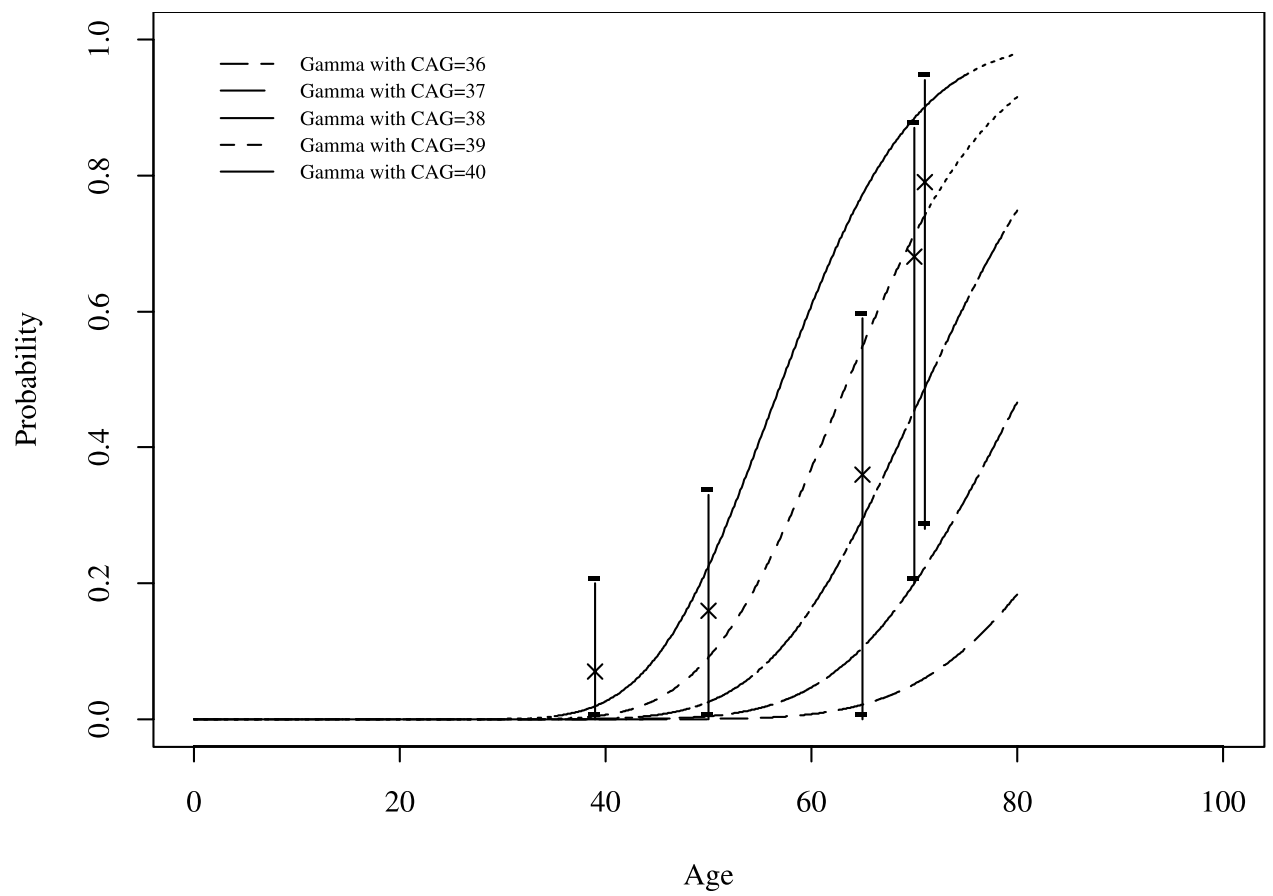

Fig. 3. Estimated penetrance with 39 CAG repeats (Brinkman et al., 1997) compared with the Gamma model fitted to 40-50 CAG repeats and extrapolated to 36-39 CAG repeats.

Survival after onset is based on Foroud et al. (1999), one reason being that their definition of onset was consistent with that used by Brinkman et al. (1997). Defining $S(d)$ to be the probability of surviving for $d$ years since onset, the model is as follows. For age at onset 20-34:

$$
1-S(d)=\frac{0.174219^{4.11789}}{\Gamma(4.11789)} \int_{0}^{d} t^{3.11789} e^{-0.174219 t} d t
$$

For age at onset 35-49:

$$
1-S(d)=\frac{0.177225^{4.35046}}{\Gamma(4.35046)} \int_{0}^{d} t^{3.35046} e^{-0.177225 t} d t
$$

For age at onset 50 and over:

$$
1-S(d)=\frac{0.183372^{4.1465}}{\Gamma(4.1465)} \int_{0}^{d} t^{3.1465} e^{-0.183372 t} d t
$$

Finally, based again on Brinkman et al. (1997) and on the models for onset and survival, the distribution at birth of CAG repeat lengths among mutation carriers was estimated as in Table 1. Following Harper, Lim \& Crawfurd (2000) we assume that 18.75 per 100,000 persons are mutation carriers.

All the details of the model can be found in Gutiérrez \& Macdonald (2002). 
Table 1. Estimated distribution of CAG repeat lengths at birth, based on numbers of asymptomatic and symptomatic individuals in Brinkman et al. (1997).

\begin{tabular}{llllllll}
\hline CAG & Proportion & CAG & Proportion & CAG & Proportion & CAG & Proportion \\
\hline 36 & 0.0124 & 40 & 0.0804 & 44 & 0.1094 & 48 & 0.0487 \\
37 & 0.0238 & 41 & 0.0983 & 45 & 0.0980 & 49 & 0.0344 \\
38 & 0.0400 & 42 & 0.1101 & 46 & 0.0824 & 50 & 0.0232 \\
39 & 0.0598 & 43 & 0.1139 & 47 & 0.0652 & & \\
\hline
\end{tabular}

\section{A CRITICAL ILLNESS INSURANCE MODEL}

\subsection{Model specification}

We wish to address two questions:

(a) If insurers do have access to genetic information relating to HD, whether that is family history or a test result, how would premiums be affected? This is the question addressed by Smith (1998) in respect of life insurance.

(b) If insurers do not have access to such information, because of a moratorium on its use, what is the potential cost, to insurers or to other insured persons, of adverse selection?

The model in Fig. 4 lets us address both questions. It is a continuous-time, discretestate Markov model representing both the $\mathrm{CI}$ insurance-buying behaviour and the claims experience of a person with a given genotype denoted $g_{\mathrm{i}}$.

(a) Fig. 4 is a model of a person's life history in an insurance market. They start uninsured in state $i 0$, and may buy a CI policy before or after having had a genetic test. If they are more likely to buy insurance after having had an adverse test result, adverse selection will appear and its cost can be measured.

(b) Premiums depending on genotype can be found simply by assuming that a person starts in one of the insured states ( $i 1$ or $i 3)$ on the policy inception date.

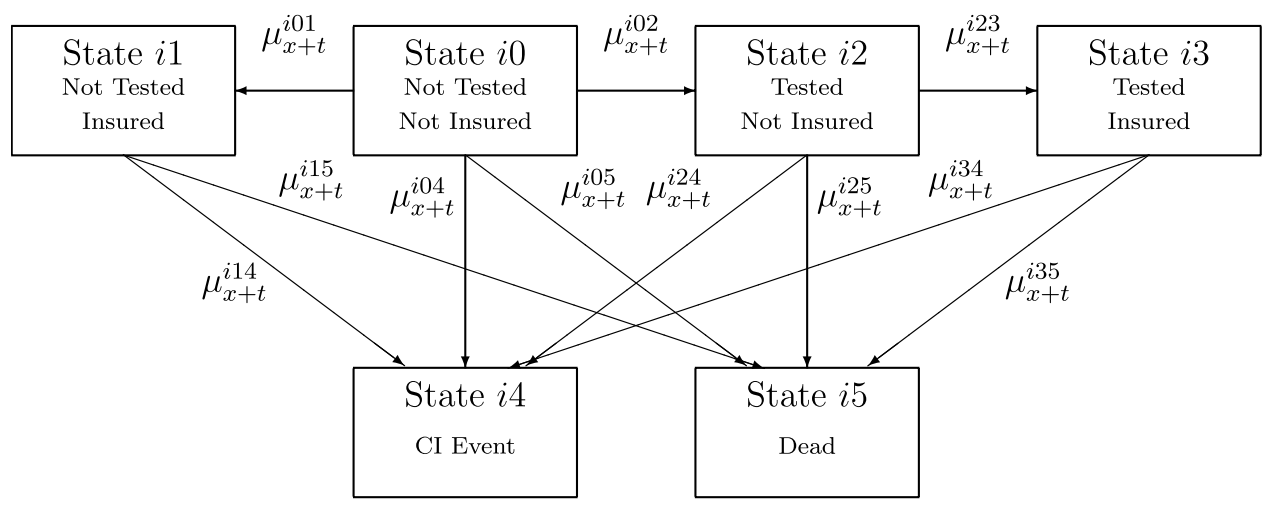

Fig. 4. A Markov model of the insurance purchase and CI insurance events for a person with genotype $g_{i}$. 


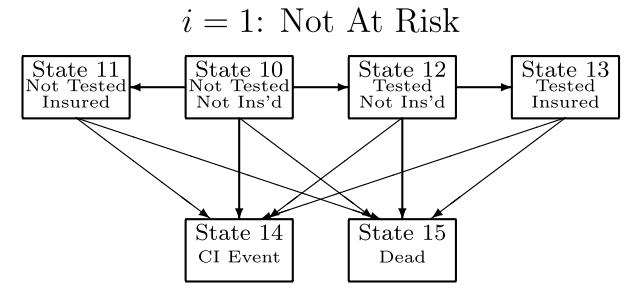

$i=2$ : At Risk, HD Mutation Absent
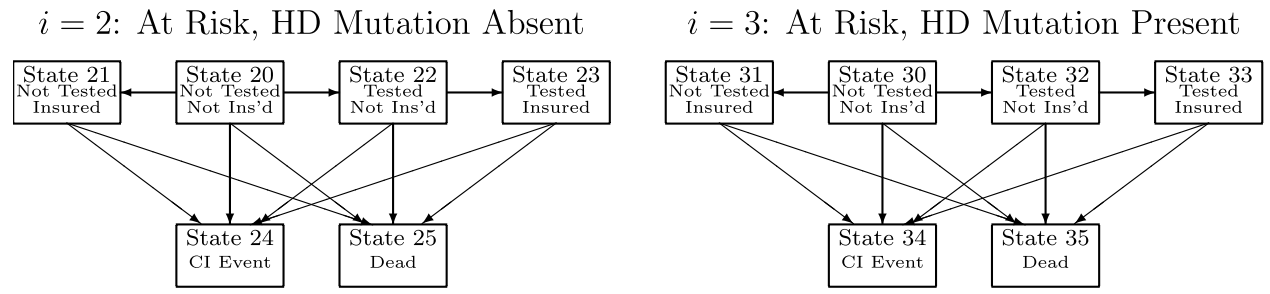

Fig. 5. A Markov model of Critical Illness insurance allowing for family history of HD and genetic testing.

Fig. 5 shows how the model is extended to the entire population allowing for genetic heterogeneity. For simplicity, it shows an aggregate model in which CAG repeat length is not considered, and a person at risk either is or is not a carrier of a HD mutation. For our later work, we have a separate sub-population for each of CAG repeat lengths 36 to 50, hence 102 states in 17 sub-populations. The proportions starting in the states labelled $i 0$ are determined by the mutation frequencies in Table 1, while intensities into the CI claiming states (i4) will depend on genotype.

As in Macdonald (2003a) or Gutiérrez \& Macdonald (2003) this model can represent many features of the problem:

(a) Mutation frequencies are the proportions in the starting states in each subpopulation.

(b) The rate of insurance purchase in the 'not at risk' sub-population will determine the market size.

(c) The rate of genetic testing is explicit.

(d) Modified insurance-buying behaviour (both rate of purchase and amount purchased):

(1) upon being heavily rated-up because of family history; or

(2) when in possession of information that need not be disclosed is represented by the rates of purchase in the appropriate at-risk sub-populations.

(e) Underwriting classes are represented by sets of insured states within each of which the same premium rate will be charged.

\subsection{Rates of onset of non-genetic critical illnesses}

There is no standard industry model for CI insurance in the U.K. or elsewhere. We use the model from Gutiérrez \& Macdonald (2003). This provides intensities of CI 
claims, and a force of mortality adjusted for CI claims, based on population data for males and females. Therefore, it is not suitable for direct application to insurance populations, but we are interested only in relative costs when the CI claim rates are augmented by onset of HD. We made no attempt to remove deaths related to HD from the population mortality, as their impact there is negligible. Other CI models have been proposed by Dinani et al. (2000) and Macdonald, Waters \& Wekwete (2003a,b).

\subsection{The timing of critical illness insurance claims}

Recall that Brinkman et al. (1997) defined age at onset as “... the first time a patient has either neurological or psychiatric symptoms that represented a permanent change from the normal state." This falls short of any criteria for a CI claim to be made, so any claim is likely to be some time after onset in the model. There are no studies of progression of HD that would allow us to specify meaningful states of health, one of which might represent a CI claim, and we are guided by two qualitative observations:

(a) Harper (1996) described three stages of HD of which the second might and the third almost certainly would lead to a successful CI claim, which would therefore be roughly 5 or 10 years after onset.

(b) The ABI's genetics adviser suggested that a CI claim might follow about 10 years after onset, in the context of preparing an application to the Genetics and Insurance Committee in the U.K. (Professor J. A. Raeburn, personal communication).

It would be possible to translate these suggestions into a simple deterministic adjustment to the model. For example, we might assume that the claim will be delayed by a certain period of $y$ years after onset, if that epoch falls within the policy term. Thus instead of paying a sum assured of $£ 1$ at onset at age $x+t$, we pay a sum of $\exp (-\delta y)$ if age $x+t+y$ falls within the policy term, or zero otherwise, where $\delta$ is the force of interest (and premiums would continue to be paid accordingly). This would entail a number of minor assumptions, such as a person with HD being removed from the risk of other CI events between onset and claim payment, but there is a more serious objection here. The ability to foresee the future, from the time of onset, makes it impossible to calculate a meaningful premium under the equivalence principle when we consider the possible costs of adverse selection (Section 5.1).

We therefore take guidance from (a) and (b) above, and the accelerated lifetime model suggests itself. Given the distribution $F_{X}(x)$ of a random variable $X$ representing a lifetime (here, the duration-dependent distribution of the lifetime after onset) we multiply the timescale by a constant $\phi \geqslant 1$ to obtain a new random variable $Y$ such that:

$F_{Y}(x)=\mathrm{P}[Y \leqslant x]=\mathrm{P}[X \leq \phi x]=F_{X}(\phi x)$.

See Collett (1994) for details. Clearly, the median of $Y$ will be $1 / \phi$ times the median of $X$. The corresponding relation between the intensities associated with $X$ and $Y$ is: 
$\mu_{Y}(x)=\phi \mu_{X}(\phi x)$.

We see that $\phi=1.5$ and $\phi=3$ correspond to claims being paid after $2 / 3$ or $1 / 3$, respectively, of the survival time after onset (on average) and this gives a simple probabilistic interpretation of Harper's three stages of HD. We will show premiums based on both of these assumptions, because it is quite possible that different insurers would apply different criteria in assessing a claim, influenced by many factors including, perhaps, public image.

The models shown in Figs. 4 and 5 correspond to $\phi=\infty$. They must be modified by the addition of a separate state representing onset of HD, with subsequent transition into the 'CI Event' state being possible, if $\phi<\infty$, but it is obvious how to do this. We assume that persons in this state (after onset but before claim payment) are still at risk of other CI events or death.

Note that the duration-dependent survival rates after onset mean that the model is semi-Markov if $\phi<\infty$. However, we can bring the computations back within a Markov framework, following Gui \& Macdonald (2002). On transition from an insured, healthy state into an insured, HD state at age $x+t$, the insurer must set up the appropriate reserve, which we denote ${ }_{t, 0} V_{x}^{H D}$ (by definition, the duration at the moment of transition is zero). All the policy values in other states remain the same if the insurer 'pays out' the amount ${ }_{t, 0} V_{x}^{H D}$ as a 'sum assured' at age $x+t$, rather than setting up the reserve, collecting further premiums and paying out subsequent $\mathrm{CI}$ claims. These amounts depend on age only, so are adapted to a Markov framework. Of course, this only works for first moments.

\subsection{Numerical methods}

Once the intensities in the model have all been fixed or estimated, we proceed by solving Kolmogorov's forward equations for occupancy probabilities, or Thiele's equations for expected present values (EPVs) of insurance cash-flows, see Hoem (1988). We used a fourth-order Runge-Kutta algorithm with step-size 0.0005 years. In all the calculations for this paper we used a force of interest of 0.05 per annum.

\section{CRITICAL ILLNESS INSURANCE UNDERWRITING}

\subsection{Underwriting with known CAG repeat length: 40-50 CAG repeats}

The only individuals who might undergo a presymptomatic genetic test for HD are blood relatives of HD sufferers. Because of its rarity and its strongly Mendelian pattern of inheritance, there are no grounds for testing someone without symptoms who does not come from an affected family. In the absence of a genetic test, someone at risk carries the mutation with a probability that depends on their relatives. For example:

(a) a person with an unaffected parent and no affected siblings, but an affected grandparent, carries the mutation with a probability that diminishes as their parent grows older and remains unaffected; or 
(b) a person with an affected parent, and who has children themselves, carries the mutation with a probability that diminishes as long as all their own children remain unaffected.

This is similar to the kind of information that might be used in life insurance underwriting, although the pedigrees used by clinical geneticists would usually be more detailed and more thoroughly checked.

We obtain level premium rates, payable continuously, for a CI insurance policy with a level sum assured, for various terms and entry ages. For 40-50 CAG repeats these are shown in Tables 2 and 3, expressed as a percentage of the standard premium rate. In Table 2 we assume that a claim is paid on reaching Stage 2 of Harper's progression, represented by $\phi=3$ in the accelerated lifetime model. In Table 3 we assume that a claim is paid on reaching Stage 3 of Harper's progression, represented by $\phi=1.5$ in the accelerated lifetime model.

(a) The stage at which a CI claim would be admitted is clearly very important. If we follow the assumption made by the ABI's genetics adviser, Table 3 might be more realistic, so our following remarks refer to it.

(b) Given that most CI insurers will decline risks rated above about 300\% to $350 \%$ of the standard premium rate, we see that a substantial number of cases are within these limits, especially for shorter terms and older ages. For example, a person age 50 could always be offered terms, even with $50 \mathrm{CAG}$ repeats. On the other hand, some premiums are extremely high, over $1,000 \%$ of the standard premium. The premiums are very dependent on the age and policy term. However, the premiums for older persons with a large number of CAG repeats are probably hypothetical as the chances of receiving such an application are small.

(c) The range of results shows that the CAG repeat length, if known, would be a most important risk factor. For example for a man age 20 and term 20 years, the premiums range from $103 \%$ to $2,674 \%$ of the standard rate. This has significant implications for policy on disclosure of genetic test results. For example, the first man above could almost certainly get cover at standard rates if he disclosed a genetic test result, but since this would be an adverse result the insurer would not be allowed to use it.

(d) The differences between males and females are because of the different standard premium rates, our HD model is for males and females combined. However, these differences are relatively trivial.

(e) This kind of information does not become irrelevant if genetic test results may not be used in underwriting, as it still contributes to an understanding of the risk pool.

(f) We remarked in Section 3.3 that the delay between onset and payment of a CI claim might most simply be represented by a deterministic period. If we assumed a delay of 10 years, consistent with payment at Stage 3 of Harper's progression, 
Table 2. Level net premium for level CI cover for persons with a known HD mutation, as a percentage of the premium for standard risks. Claims arising at Stage 2 of Harper's progression.

\begin{tabular}{|c|c|c|c|c|c|c|c|c|c|c|c|c|c|}
\hline \multirow[b]{2}{*}{$\begin{array}{l}\text { Sex of } \\
\text { Applicant }\end{array}$} & \multirow[b]{2}{*}{$\begin{array}{l}\text { Age at Entry } \\
\text { (Years) }\end{array}$} & \multirow[b]{2}{*}{$\begin{array}{l}\text { Policy Term } \\
\text { (Years) }\end{array}$} & \multicolumn{11}{|c|}{ Number of CAG Repeats } \\
\hline & & & $\begin{array}{l}40 \\
\%\end{array}$ & $\begin{array}{l}41 \\
\%\end{array}$ & $\begin{array}{l}42 \\
\%\end{array}$ & $\begin{array}{l}43 \\
\%\end{array}$ & $\begin{array}{l}44 \\
\%\end{array}$ & $\begin{array}{l}45 \\
\%\end{array}$ & $\begin{array}{l}46 \\
\%\end{array}$ & $\begin{array}{l}47 \\
\%\end{array}$ & $\begin{array}{l}48 \\
\%\end{array}$ & $\begin{array}{l}49 \\
\%\end{array}$ & $\begin{array}{l}50 \\
\%\end{array}$ \\
\hline \multirow[t]{10}{*}{ Female } & \multirow[t]{4}{*}{20} & 10 & 100 & 101 & 107 & 125 & 176 & 294 & 523 & 911 & 1,487 & 2,249 & 3,168 \\
\hline & & 20 & 111 & 141 & 221 & 389 & 682 & 1,118 & 1,690 & 2,373 & 3,125 & 3,907 & 4,680 \\
\hline & & 30 & 168 & 270 & 442 & 683 & 978 & 1,311 & 1,667 & 2,040 & 2,424 & 2,816 & 3,208 \\
\hline & & 40 & 246 & 361 & 502 & 658 & 828 & 1,013 & 1,215 & 1,437 & 1,676 & 1,928 & 2,185 \\
\hline & \multirow[t]{3}{*}{30} & 10 & 115 & 154 & 249 & 429 & 705 & 1,066 & 1,480 & 1,913 & 2,336 & 2,732 & 3,091 \\
\hline & & 20 & 183 & 308 & 515 & 800 & 1,137 & 1,492 & 1,837 & 2,154 & 2,434 & 2,676 & 2,882 \\
\hline & & 30 & 268 & 406 & 578 & 771 & 975 & 1,181 & 1,380 & 1,565 & 1,732 & 1,880 & 2,007 \\
\hline & \multirow[t]{2}{*}{40} & 10 & 180 & 274 & 405 & 559 & 718 & 871 & 1,011 & 1,136 & 1,246 & 1,341 & 1,424 \\
\hline & & 20 & 298 & 443 & 604 & 760 & 899 & 1,018 & 1,117 & 1,199 & 1,268 & 1,324 & 1,372 \\
\hline & 50 & 10 & 247 & 330 & 414 & 494 & 567 & 630 & 685 & 733 & 774 & 809 & 840 \\
\hline \multirow[t]{10}{*}{ Male } & \multirow[t]{4}{*}{20} & 10 & 100 & 102 & 112 & 143 & 231 & 433 & 828 & 1,495 & 2,485 & 3,796 & 5,376 \\
\hline & & 20 & 115 & 159 & 275 & 519 & 942 & 1,574 & 2,403 & 3,392 & 4,482 & 5,614 & 6,736 \\
\hline & & 30 & 180 & 300 & 503 & 787 & 1,136 & 1,529 & 1,951 & 2,392 & 2,848 & 3,312 & 3,776 \\
\hline & & 40 & 242 & 356 & 495 & 651 & 821 & 1,007 & 1,211 & 1,435 & 1,677 & 1,931 & 2,190 \\
\hline & \multirow[t]{3}{*}{30} & 10 & 120 & 171 & 297 & 534 & 900 & 1,376 & 1,923 & 2,494 & 3,054 & 3,577 & 4,051 \\
\hline & & 20 & 192 & 328 & 556 & 869 & 1,239 & 1,629 & 2,009 & 2,358 & 2,666 & 2,932 & 3,159 \\
\hline & & 30 & 256 & 385 & 546 & 728 & 921 & 1,117 & 1,306 & 1,483 & 1,642 & 1,782 & 1,904 \\
\hline & \multirow[t]{2}{*}{40} & 10 & 179 & 273 & 403 & 556 & 714 & 866 & 1,005 & 1,129 & 1,238 & 1,333 & 1,415 \\
\hline & & 20 & 271 & 396 & 535 & 671 & 792 & 896 & 982 & 1,054 & 1,114 & 1,164 & 1,205 \\
\hline & 50 & 10 & 216 & 281 & 348 & 411 & 468 & 518 & 562 & 599 & 632 & 660 & 684 \\
\hline
\end{tabular}


Table 3. Level net premium for level CI cover for persons with a known HD mutation, as a percentage of the premium for standard risks. Claims arising at Stage 3 of Harper's progression.

\begin{tabular}{|c|c|c|c|c|c|c|c|c|c|c|c|c|c|}
\hline \multirow[b]{2}{*}{$\begin{array}{l}\text { Sex of } \\
\text { Applicant }\end{array}$} & \multirow[b]{2}{*}{$\begin{array}{l}\text { Age at Entry } \\
\text { (Years) }\end{array}$} & \multirow[b]{2}{*}{$\begin{array}{l}\text { Policy Term } \\
\text { (Years) }\end{array}$} & \multicolumn{11}{|c|}{ Number of CAG Repeats } \\
\hline & & & $\begin{array}{l}40 \\
\%\end{array}$ & $\begin{array}{l}41 \\
\%\end{array}$ & $\begin{array}{l}42 \\
\%\end{array}$ & $\begin{array}{l}43 \\
\%\end{array}$ & $\begin{array}{l}44 \\
\%\end{array}$ & $\begin{array}{l}45 \\
\%\end{array}$ & $\begin{array}{l}46 \\
\%\end{array}$ & $\begin{array}{l}47 \\
\%\end{array}$ & $\begin{array}{l}48 \\
\%\end{array}$ & $\begin{array}{l}49 \\
\%\end{array}$ & $\begin{array}{l}50 \\
\%\end{array}$ \\
\hline \multirow[t]{10}{*}{ Female } & \multirow[t]{4}{*}{20} & 10 & 100 & 100 & 101 & 104 & 113 & 134 & 178 & 255 & 374 & 537 & 738 \\
\hline & & 20 & 102 & 109 & 130 & 176 & 266 & 412 & 621 & 888 & 1,200 & 1,536 & 1,877 \\
\hline & & 30 & 119 & 153 & 219 & 323 & 467 & 643 & 842 & 1,054 & 1,270 & 1,479 & 1,678 \\
\hline & & 40 & 157 & 214 & 291 & 386 & 492 & 607 & 728 & 853 & 979 & 1,104 & 1,223 \\
\hline & \multirow[t]{3}{*}{30} & 10 & 103 & 110 & 130 & 167 & 227 & 307 & 401 & 500 & 598 & 690 & 775 \\
\hline & & 20 & 123 & 163 & 236 & 346 & 482 & 632 & 779 & 915 & 1,034 & 1,136 & 1,221 \\
\hline & & 30 & 165 & 230 & 317 & 420 & 529 & 635 & 733 & 818 & 891 & 951 & 1,002 \\
\hline & \multirow[t]{2}{*}{40} & 10 & 115 & 134 & 160 & 192 & 225 & 257 & 287 & 314 & 338 & 360 & 378 \\
\hline & & 20 & 169 & 225 & 289 & 351 & 407 & 455 & 494 & 526 & 552 & 573 & 591 \\
\hline & 50 & 10 & 133 & 153 & 173 & 192 & 209 & 224 & 238 & 249 & 260 & 269 & 276 \\
\hline \multirow[t]{10}{*}{ Male } & \multirow[t]{4}{*}{20} & 10 & 100 & 100 & 102 & 107 & 122 & 159 & 235 & 367 & 571 & 851 & 1,198 \\
\hline & & 20 & 103 & 113 & 143 & 211 & 340 & 552 & 855 & 1,242 & 1,693 & 2,181 & 2,674 \\
\hline & & 30 & 123 & 163 & 240 & 363 & 532 & 740 & 976 & 1,227 & 1,481 & 1,729 & 1,964 \\
\hline & & 40 & 156 & 211 & 288 & 381 & 487 & 601 & 723 & 848 & 975 & 1,100 & 1,220 \\
\hline & \multirow[t]{3}{*}{30} & 10 & 104 & 114 & 139 & 189 & 268 & 374 & 497 & 628 & 757 & 880 & 992 \\
\hline & & 20 & 125 & 169 & 250 & 370 & 520 & 684 & 846 & 995 & 1,126 & 1,238 & 1,331 \\
\hline & & 30 & 160 & 220 & 302 & 398 & 501 & 601 & 692 & 773 & 842 & 900 & 947 \\
\hline & \multirow{2}{*}{40} & 10 & 115 & 134 & 160 & 191 & 224 & 256 & 286 & 313 & 337 & 358 & 376 \\
\hline & & 20 & 159 & 207 & 262 & 316 & 365 & 406 & 440 & 467 & 490 & 509 & 524 \\
\hline & 50 & 10 & 126 & 141 & 157 & 172 & 186 & 198 & 208 & 218 & 226 & 233 & 239 \\
\hline
\end{tabular}


then no 10-year policies would have a premium higher than standard. Table 3 shows that this would be very misleading; with a high number of CAG repeats, even 10 -year policies can attract a very high rating. This is a striking example of the errors that can be made if key stochastic features of a model are replaced by deterministic 'equivalents', even if they appear to be chosen sensibly.

\subsection{Underwriting with known CAG repeat length: 36-39 CAG repeats}

Tables 4 and 5 show the level CI premiums, as a percentage of the standard premiums, with intermediate alleles of 36-39 CAG repeats. In Table 4 we assume that a claim is paid on reaching Stage 2 of Harper's progression, represented by $\phi=3$ in the accelerated lifetime model. In Table 4 we assume that a claim is paid on reaching Stage 3 of Harper's progression, represented by $\phi=1.5$ in the accelerated lifetime model.

The results are quite striking. Only with 38 or more CAG repeats (in Table 4) or 39 CAG repeats (in Table 5) would there be any real question of a premium higher than standard, and then only for longer terms. Even if our extrapolated function is only right in its general features, we can conclude that access to CI insurance should be possible for anyone with a presymptomatic test result in the intermediate range, and mostly at standard rates. This is much more encouraging than might previously have been supposed.

We stress that our model for intermediate alleles is based on extrapolating the function fitted to 40-50 CAG repeats, and there were no data for 36-38 CAG repeats in Brinkman et al. (1997). However, the extra premiums are sufficiently low that we think our conclusions are robust.

\subsection{Underwriting based on family history only}

If an applicant of a given age has a family history of $\mathrm{HD}$, but no genetic test result is known, a level premium is computed using the equivalence principle, where the expected present values (EPVs) of a unit benefit and a unit premium are weighted averages of the EPVs in respect of each possible genotype (including non-carriers), the weights being the probabilities of being alive and healthy at the given age. These are obtained as the occupancy probabilities in a model in which, at age 20, half of all persons at risk are non-carriers, and the other half have CAG repeat lengths distributed according to Table 1 .

Table 6 shows the level CI premiums as a percentage of standard premiums. Again, the stage at which a claim would be made has the greatest bearing on the results. If it is at Stage 3 of Harper's progression, then all but young persons seeking very longterm cover could be offered terms, and older persons could be offered rates close to standard. We would expect premiums to fall with age, because survival free of symptoms increases the chance of not being a carrier. However, this pattern of premiums may give rise to a lapse and re-entry risk. We have assumed that level premiums will be payable throughout the term of a policy, but for longer policy terms 
Table 4. Level net premium for level CI cover for persons with a known 'intermediate allele' HD mutation (36-39 CAG repeats), as a percentage of the premium for standard risks. Claims arising at Stage 2 of Harper's progression.

\begin{tabular}{|c|c|c|c|c|c|c|c|c|c|}
\hline \multirow[b]{3}{*}{$\begin{array}{l}\text { Age at Entry } \\
\text { (Years) }\end{array}$} & \multirow[b]{3}{*}{$\begin{array}{l}\text { Policy Term } \\
\text { (Years) }\end{array}$} & \multicolumn{8}{|c|}{ Premium as Percentage of Standard } \\
\hline & & \multicolumn{4}{|c|}{$\begin{array}{l}\text { Females } \\
\text { No. of CAG Repeats }\end{array}$} & \multicolumn{4}{|c|}{$\begin{array}{l}\text { Males } \\
\text { No. of CAG Repeats }\end{array}$} \\
\hline & & $\begin{array}{l}36 \\
\%\end{array}$ & $\begin{array}{l}37 \\
\%\end{array}$ & $\begin{array}{l}38 \\
\%\end{array}$ & $\begin{array}{l}39 \\
\%\end{array}$ & $\begin{array}{l}36 \\
\%\end{array}$ & $\begin{array}{l}37 \\
\%\end{array}$ & $\begin{array}{l}38 \\
\%\end{array}$ & $\begin{array}{l}39 \\
\%\end{array}$ \\
\hline \multirow[t]{4}{*}{20} & 10 & 100 & 100 & 100 & 100 & 100 & 100 & 100 & 100 \\
\hline & 20 & 100 & 100 & 100 & 102 & 100 & 100 & 100 & 103 \\
\hline & 30 & 100 & 101 & 104 & 120 & 100 & 101 & 105 & 124 \\
\hline & 40 & 101 & 105 & 121 & 165 & 101 & 104 & 121 & 163 \\
\hline \multirow[t]{3}{*}{30} & 10 & 100 & 100 & 100 & 103 & 100 & 100 & 101 & 104 \\
\hline & 20 & 100 & 101 & 105 & 125 & 100 & 101 & 106 & 128 \\
\hline & 30 & 101 & 105 & 124 & 174 & 101 & 105 & 122 & 169 \\
\hline \multirow[t]{2}{*}{40} & 10 & 100 & 101 & 106 & 127 & 100 & 101 & 106 & 127 \\
\hline & 20 & 101 & 107 & 130 & 191 & 101 & 106 & 126 & 178 \\
\hline 50 & 10 & 101 & 107 & 130 & 177 & 101 & 106 & 123 & 160 \\
\hline
\end{tabular}


Table 5. Level net premium for level CI cover for persons with a known 'intermediate allele' HD mutation (36-39 CAG repeats), as a percentage of the premium for standard risks. Claims arising at Stage 3 of Harper's progression.

\begin{tabular}{|c|c|c|c|c|c|c|c|c|c|}
\hline \multirow[b]{3}{*}{$\begin{array}{l}\text { Age at Entry } \\
\text { (Years) }\end{array}$} & \multirow[b]{3}{*}{$\begin{array}{l}\text { Policy Term } \\
\text { (Years) }\end{array}$} & \multicolumn{8}{|c|}{ Premium as Percentage of Standard } \\
\hline & & \multicolumn{4}{|c|}{$\begin{array}{l}\text { Females } \\
\text { No. of CAG Repeats }\end{array}$} & \multicolumn{4}{|c|}{$\begin{array}{l}\text { Males } \\
\text { No. of CAG Repeats }\end{array}$} \\
\hline & & $\begin{array}{l}36 \\
\%\end{array}$ & $\begin{array}{l}37 \\
\%\end{array}$ & $\begin{array}{l}38 \\
\%\end{array}$ & $\begin{array}{l}39 \\
\%\end{array}$ & $\begin{array}{l}36 \\
\%\end{array}$ & $\begin{array}{l}37 \\
\%\end{array}$ & $\begin{array}{l}38 \\
\%\end{array}$ & $\begin{array}{l}39 \\
\%\end{array}$ \\
\hline \multirow[t]{4}{*}{20} & 10 & 100 & 100 & 100 & 100 & 100 & 100 & 100 & 100 \\
\hline & 20 & 100 & 100 & 100 & 100 & 100 & 100 & 100 & 101 \\
\hline & 30 & 100 & 100 & 101 & 105 & 100 & 100 & 101 & 106 \\
\hline & 40 & 100 & 101 & 107 & 123 & 100 & 101 & 106 & 122 \\
\hline \multirow[t]{3}{*}{30} & 10 & 100 & 100 & 100 & 101 & 100 & 100 & 100 & 101 \\
\hline & 20 & 100 & 100 & 101 & 106 & 100 & 100 & 101 & 107 \\
\hline & 30 & 100 & 101 & 108 & 126 & 100 & 101 & 107 & 124 \\
\hline \multirow[t]{2}{*}{40} & 10 & 100 & 100 & 101 & 105 & 100 & 100 & 101 & 105 \\
\hline & 20 & 100 & 102 & 109 & 130 & 100 & 102 & 108 & 125 \\
\hline 50 & 10 & 100 & 102 & 106 & 117 & 100 & 101 & 105 & 113 \\
\hline
\end{tabular}


Table 6. Level net premiums for CI cover as a percentage of the premium for standard risks, for persons with a family history of $H D$ (affected parent or sibling).

\begin{tabular}{|c|c|c|c|c|c|}
\hline \multirow[b]{3}{*}{$\begin{array}{l}\text { Age at Entry } \\
\text { (Years) }\end{array}$} & \multirow[b]{3}{*}{$\begin{array}{l}\text { Policy Term } \\
\text { (Years) }\end{array}$} & \multicolumn{4}{|c|}{ Claims arising } \\
\hline & & \multicolumn{2}{|c|}{ At Stage 2 of Harper (1996) } & \multicolumn{2}{|c|}{ At Stage 3 of Harper (1996) } \\
\hline & & $\begin{array}{l}\text { Females } \\
\%\end{array}$ & $\begin{array}{l}\text { Males } \\
\%\end{array}$ & $\begin{array}{l}\text { Females } \\
\%\end{array}$ & $\begin{array}{l}\text { Males } \\
\%\end{array}$ \\
\hline \multirow[t]{4}{*}{20} & 10 & 263 & 380 & 132 & 156 \\
\hline & 20 & 503 & 684 & 246 & 311 \\
\hline & 30 & 480 & 549 & 289 & 323 \\
\hline & 40 & 388 & 387 & 268 & 266 \\
\hline \multirow[t]{3}{*}{30} & 10 & 266 & 320 & 137 & 148 \\
\hline & 20 & 335 & 358 & 195 & 204 \\
\hline & 30 & 296 & 284 & 203 & 197 \\
\hline \multirow[t]{2}{*}{40} & 10 & 172 & 171 & 115 & 115 \\
\hline & 20 & 202 & 188 & 142 & 136 \\
\hline 50 & 10 & 128 & 122 & 107 & 105 \\
\hline
\end{tabular}

it might be advisable in practice to charge a higher extra premium for a shorter term (as recommended by Brackenridge \& Elder (1998) for life insurance).

It is often supposed that, even if a moratorium is imposed on the use of genetic test results, persons who disclose a 'clear' result will be underwritten as normal. However the fact that premiums given a family history in some cases (younger persons, up to 44 CAG repeats) lie within the range of premiums defined by individual CAG repeat lengths raises awkward questions about how far this 'common sense' approach might extend. We discuss this in detail in Section 9.3.

\subsection{Ascertainment bias and underwriting}

Ascertainment is the process by which persons or families come to the attention of researchers. It is usually presumed that ascertainment is incomplete, because persons with milder symptoms or later onset, or families with few affected members, will be more easily overlooked. The effect of under-ascertainment is to overstate estimates of rates of onset. It is regarded as a central problem in genetic epidemiology.

Falush et al. (2000), found under-ascertainment with 40 CAG repeats, and extreme under-ascertainment with 36-38 CAG repeats. We could conclude from this that the figures in Tables 4 and 5 should be even lower than they are. However, an applicant for insurance with a known number of CAG repeats in the intermediate range is presumably a member of the 'ascertained' group, just because they have been tested, so it is more reasonable to say that the rates of onset, overstated because of low ascertainment, are in fact appropriate for the group of tested individuals.

In general, it is possible that under-ascertainment is less relevant in actuarial studies than it is in epidemiology, at least as far as genetic testing is concerned. It results in estimated rates of onset for a selected group rather than for the population, but it is just the same selected group who would ever approach an insurer with 
knowledge of a test result (whether or not they had to disclose it). This does assume that genetic tests for severe disorders are only ever taken for a reason, which is likely to be true in the U.K. but perhaps not everywhere else.

\section{CRITICAL ILLNESS INSURANCE AND ADVERSE SELECTION}

\subsection{Adverse selection and moratoria on genetic information in underwriting}

Macdonald (2003a) and Gutiérrez \& Macdonald (2003) used the model in Fig. 4 to illustrate the potential costs arising from adverse selection if there were a moratorium on the use of genetic information in underwriting. The current position in the U.K. is that genetic test results may not be used for life insurance of up to $£ 500,000$ or other forms of insurance of up to $£ 300,000$, but family history can still be used. In some other countries (Sweden for example) family history also may not be used.

The methodology has been extensively discussed in the two papers cited above, so we will just summarise it here:

(a) An underwriting class is defined as a set of (insured) states in the model, within each of which the same rate of premium will be charged. In the absence of a moratorium the insurer would presumably partition the states according to homogeneity of risks, but a moratorium may force very different risks into the same underwriting class.

(b) The rate of premium within each underwriting class is calculated using the equivalence principle. However, level premiums cannot be used because they depend on age at purchase of insurance, so that a person in one of the insured states at age 50 (say) would pay a different rate of premium if they had entered it at age 30 than if they had entered it at age 40. This is not compatible with Thiele's equations. The solution is to charge a rate of premium equal to the weighted average of the intensities from the insured states in the underwriting class to the CI claim state. If $\mathscr{C}$ is a set of states representing an underwriting class, the rate of premium is:

$\rho_{x+t}^{\mathscr{C}}=\frac{\sum_{i j \in \mathscr{C}} p_{i t} p_{x}^{i 0 j} \mu_{x+t}^{i j 4}}{\sum_{i j \in \mathscr{C}} p_{i_{t}} p_{x}^{i 0 j}}$

where $p_{i}$ is the proportion who start in state $i 0$ at age $x$ and ${ }_{t} p_{x}^{i 0 j}$ is the probability of being in state $i j$ at age $x+t$, if in state $i 0$ at age $x$. This device means that we must first solve Kolmogorov's equations to obtain the occupancy probabilities, then solve Thiele's equations using these rates of premium.

(c) The result of solving Thiele's equations is the EPV of the insurance loss conditional on being in any state. The weighted average of these EPVs in the starting states (10, 20 and so on), the weights being the occupancy probabilities 
at outset based on the mutation frequencies, is the EPV of the insurance loss in respect of the entire market.

(d) The insurer calculates the rates of premium assuming no adverse selection takes place. If this is borne out, the EPV of the loss is zero, because the equivalence principle has been correctly applied. If there is adverse selection, however, the EPV of the loss will be non-zero. This is the 'cost' of adverse selection. To recoup it, the insurer would have to increase premiums by:

EPV of loss with adverse selection

EPV of premiums payable with adverse selection

and this is the quantity that we take as our measure of the cost of adverse selection.

\subsection{Parameterisation}

We must choose intensities to represent 'normal' insurance purchase in each underwriting class, adverse selection, and genetic testing. To a large extent these are speculative:

(a) the CI insurance market is small but growing in the U.K., or hardly established in most other countries;

(b) little is known about how peoples' insurance-buying behaviour is changed by knowledge of genetic risks; and

(c) genetic testing is in its infancy.

We represent larger and smaller markets by constant rates of insurance purchase of 0.05 or 0.01 per annum, respectively, over the age range $20-60$. That is, we assume that the market operates between these ages, and all CI policies have cover expiring at age 60. Clearly this could be refined if age-related rates of purchase were available. However, persons offered a much higher premium because of a family history of HD might not be so likely to buy insurance; to cover the range of possibilities we suppose that in the larger market they buy insurance at rate $0.05,0.025$ or 0 per annum (the latter could also represent declinature on the part of the insurer) and in the smaller market we suppose that they do not buy insurance at all. This too could be refined, if we had a good model of the elasticity of demand for CI insurance. A moderate level of adverse selection is represented by intensities of 0.1 in the larger market, and 0.02 in the smaller market (twice the 'normal' rates). A severe level of adverse selection is represented by an intensity of 0.25 per annum; this is so high that most people will have bought insurance within a few years.

With testing having been widely available since about 1994 , about $10-20 \%$ of atrisk persons have been tested (Meiser \& Dunn, 2000). We assume that most testing takes place at relatively young ages, in the model at ages $20-40$. A rate of 0.014 per annum over these ages means that about $10 \%$ would be tested after 8 years (and 24\% 
after 20 years) thus representing a modest rate of testing. We take this as our baseline, and compare it with:

(a) the same rate of testing of 0.014 per annum, but extending over ages 20-60; and

(b) a rate of testing of 0.035 per annum, over ages $20-40$.

On balance, we believe that the baseline rate of testing, low and in line with observed prevalence, is most appropriate. Perhaps the most plausible reason for higher rates of testing in future might be the development of effective treatments for HD, which would offset any increase in costs, although in ways impossible to predict. It is the combination of high rates of testing and no treatment at all that seems least plausible.

\subsection{Moratoria on genetic test results}

A moratorium may forbid the use of all genetic test results, or (perhaps more likely) allow the use of negative test results that would allow someone to be offered the standard premium rate. In either case there will be two underwriting classes: one including everyone charged the standard premium, and another whose members will be offered a premium based on family history.

Tables 7 and 8 show the percentage premium increases needed to recoup the cost of moderate adverse selection in respect of undisclosed genetic tests for HD mutations, assumes claims arise at Stage 2 or Stage 3, respectively, of Harper's progression. They are all small (less than $0.02 \%$ ) but there is a pattern:

(a) They increase substantially, the less people at risk take up the offer of insurance at premiums increased because of family history. It is probably most realistic to suppose that such persons do not buy insurance, because they often might not be offered it.

(b) The costs are much more substantial in the smaller market.

(c) The costs are very slightly higher under the moratorium on adverse test results only. As in Gutiérrez \& Macdonald (2003), this is because the premium rate in the 'family history' underwriting class is now more heavily weighted by mutation carriers.

(d) Extending the period during which genetic testing is assumed to take place has little effect. Mainly this is because of the high penetrance of HD mutations; relatively few mutation carriers will ever undergo a presymptomatic test after age 40. Increasing the rate at which testing takes place, however, increases the costs substantially.

The small magnitude of these costs, even assuming very severe adverse selection, cannot by itself be taken to mean that all genetic testing is irrelevent for $\mathrm{CI}$ insurance. $\mathrm{HD}$ is one, quite rare, member of the universe of genetic disorders, and we would have to complete a program of modelling the others before we could reach any such conclusion. 
Table 7. Percentage increases in CI insurance premium rates arising from moderate adverse selection. Moratoria on the use of genetic test results, family history underwriting still allowed. CI market operating between ages 20 and 60. Claims arising at Stage 2 of Harper's progression.

\begin{tabular}{|c|c|c|c|c|c|c|c|}
\hline \multirow[b]{3}{*}{$\begin{array}{l}\text { Size of } \\
\text { Market }\end{array}$} & \multirow[b]{3}{*}{$\begin{array}{l}\text { Insurance Purchasing of } \\
\text { At-Risk Individuals }\end{array}$} & \multirow[b]{3}{*}{$\begin{array}{l}\text { Rate of } \\
\text { Testing }\end{array}$} & \multirow[b]{3}{*}{$\begin{array}{l}\text { Age Range } \\
\text { of Testing }\end{array}$} & \multicolumn{4}{|c|}{ Moratorium on Using } \\
\hline & & & & \multicolumn{2}{|c|}{ All test results } & \multicolumn{2}{|c|}{$\begin{array}{l}\text { Adverse test } \\
\text { results }\end{array}$} \\
\hline & & & & $\begin{array}{l}\text { Females } \\
\%\end{array}$ & $\begin{array}{l}\text { Males } \\
\%\end{array}$ & $\begin{array}{l}\text { Females } \\
\%\end{array}$ & $\begin{array}{l}\text { Males } \\
\%\end{array}$ \\
\hline \multirow[t]{3}{*}{ Large } & Normal & 0.014 & $20-40$ & 0.002 & 0.002 & 0.002 & 0.002 \\
\hline & Half & 0.014 & $20-40$ & 0.005 & 0.004 & 0.004 & 0.004 \\
\hline & Nil & 0.014 & $20-40$ & 0.009 & 0.008 & 0.008 & 0.008 \\
\hline Small & Nil & 0.014 & $20-40$ & 0.008 & 0.008 & 0.008 & 0.007 \\
\hline \multirow[t]{3}{*}{ Large } & Normal & 0.014 & $20-60$ & 0.002 & 0.002 & 0.002 & 0.002 \\
\hline & Half & 0.014 & $20-60$ & 0.005 & 0.004 & 0.004 & 0.004 \\
\hline & Nil & 0.014 & $20-60$ & 0.009 & 0.009 & 0.009 & 0.008 \\
\hline Small & Nil & 0.014 & $20-60$ & 0.009 & 0.008 & 0.008 & 0.007 \\
\hline \multirow[t]{3}{*}{ Large } & Normal & 0.035 & $20-40$ & 0.005 & 0.005 & 0.004 & 0.004 \\
\hline & Half & 0.035 & $20-40$ & 0.010 & 0.010 & 0.009 & 0.009 \\
\hline & Nil & 0.035 & $20-40$ & 0.020 & 0.019 & 0.017 & 0.016 \\
\hline Small & Nil & 0.035 & $20-40$ & 0.019 & 0.017 & 0.015 & 0.014 \\
\hline
\end{tabular}

5.4. Moratoria on family history and genetic test results

A moratorium on family history as well as genetic tests has two results:

(a) Those who were previously in higher-risk underwriting classes can now buy insurance in the normal way; that is, at the same rate as persons not at risk. This will increase premiums, but it is not adverse selection. We call this the cost of defining new underwriting classes. Note that it does not depend on the rate at which at-risk persons previously bought insurance.

(b) However, these same peoples' knowledge of their genetic risk might lead them to buy insurance at a rate higher than normal, so there might be further premium increases for that reason. Moreover, this group now includes those who have a family history but who have not been tested, which means that the rate of genetic testing is relevant only to the extent that testing removes non-carriers from the at-risk group.

Tables 9 and 10 show these two levels of premium increases separately, assuming claims arise at Stage 2 or Stage 3, respectively, of Harper's progression. Both moderate and severe levels of adverse selection are shown (see Section 5.6). The rate of genetic testing was 0.014 per annum with moderate adverse selection, and 0.035 per annum with severe adverse selection, between ages 20 and 40; other assumptions made almost no difference and we omit them. In the large market, the cost of the new underwriting class is high compared with the previous costs of a moratorium on 
Table 8. Percentage increases in CI insurance premium rates arising from moderate adverse selection. Moratoria on the use of genetic test results, family history underwriting still allowed. CI market operating between ages 20 and 60. Claims arising at Stage 3 of Harper's progression.

\begin{tabular}{|c|c|c|c|c|c|c|c|}
\hline \multirow[b]{3}{*}{$\begin{array}{l}\text { Size of } \\
\text { Market }\end{array}$} & \multirow[b]{3}{*}{$\begin{array}{l}\text { Insurance Purchasing of } \\
\text { At-Risk Individuals }\end{array}$} & \multirow[b]{3}{*}{$\begin{array}{l}\text { Rate of } \\
\text { Testing }\end{array}$} & \multirow[b]{3}{*}{$\begin{array}{l}\text { Age Range } \\
\text { of Testing }\end{array}$} & \multicolumn{4}{|c|}{ Moratorium on Using } \\
\hline & & & & \multicolumn{2}{|c|}{ All test results } & \multicolumn{2}{|c|}{$\begin{array}{l}\text { Adverse test } \\
\text { results }\end{array}$} \\
\hline & & & & $\begin{array}{l}\text { Females } \\
\%\end{array}$ & $\begin{array}{l}\text { Males } \\
\%\end{array}$ & $\begin{array}{l}\text { Females } \\
\%\end{array}$ & $\begin{array}{l}\text { Males } \\
\%\end{array}$ \\
\hline \multirow[t]{3}{*}{ Large } & Normal & 0.014 & $20-40$ & 0.001 & 0.001 & 0.001 & 0.001 \\
\hline & Half & 0.014 & $20-40$ & 0.002 & 0.002 & 0.002 & 0.002 \\
\hline & Nil & 0.014 & $20-40$ & 0.005 & 0.004 & 0.004 & 0.004 \\
\hline Small & Nil & 0.014 & $20-40$ & 0.004 & 0.003 & 0.003 & 0.003 \\
\hline \multirow[t]{3}{*}{ Large } & Normal & 0.014 & $20-60$ & 0.001 & 0.001 & 0.001 & 0.001 \\
\hline & Half & 0.014 & $20-60$ & 0.002 & 0.002 & 0.002 & 0.002 \\
\hline & Nil & 0.014 & $20-60$ & 0.004 & 0.004 & 0.004 & 0.004 \\
\hline Small & Nil & 0.014 & $20-60$ & 0.004 & 0.003 & 0.003 & 0.003 \\
\hline \multirow[t]{3}{*}{ Large } & Normal & 0.035 & $20-40$ & 0.003 & 0.003 & 0.002 & 0.002 \\
\hline & Half & 0.035 & $20-40$ & 0.006 & 0.005 & 0.005 & 0.004 \\
\hline & Nil & 0.035 & $20-40$ & 0.010 & 0.010 & 0.008 & 0.008 \\
\hline Small & Nil & 0.035 & $20-40$ & 0.009 & 0.008 & 0.007 & 0.006 \\
\hline
\end{tabular}

adverse selection, approaching $0.07 \%$, in Table 9 , and the cost of further adverse selection is about half as much again. In the smaller market, the cost of additional (severe) adverse selection is higher, exceeding $0.05 \%$. But in absolute terms these increases are negligible.

\subsection{Higher sums assured}

All the results shown here suppose that 'adverse selectors' buy the same amount of insurance as normal; they do not insure themselves for above-average amounts. This possibility is the second component of adverse selection. It is easy to see that in this case, the premium increases are proportionate to the multiple of the average sum assured taken out by 'adverse selectors', so for brevity we omit the tables.

\subsection{More extreme adverse selection}

Our 'severe' rate of adverse selection, 0.25 per annum, is deliberately extreme. It implies that nearly all people in a position to exploit non-disclosure will do so within a few years. Arguably this is unlikely, but to show the worst that might be expected we combine severe adverse selection with a higher rate of genetic testing $(0.035$ per annum up to age 40). Tables 9 and 10 included the results for a moratorium on family history, and Tables 11 and 12 show the costs of moratoria on genetic test results, assuming CI claims to be paid at Stage 2 or Stage 3, respectively, of Harper's progression: 
Table 9. Percentage increases in standard premium rates for CI insurance arising from new underwriting classes, and in all premiums arising from moderate or severe adverse selection, following a moratorium on the use of all genetic test results and family history. CI market operating between ages 20 and 60. Claims arising at Stage 2 of Harper's progression.

\begin{tabular}{|c|c|c|c|c|c|c|}
\hline \multirow[b]{2}{*}{$\begin{array}{l}\text { Size of } \\
\text { Market }\end{array}$} & \multicolumn{2}{|c|}{$\begin{array}{l}\text { OR Premium Increases } \\
\text { Arising From New } \\
\text { Underwriting Classes }\end{array}$} & \multicolumn{2}{|c|}{$\begin{array}{l}\text { Premium Increases } \\
\text { Arising From Moderate } \\
\text { Adverse Selection }\end{array}$} & \multicolumn{2}{|c|}{$\begin{array}{l}\text { Premium Increases } \\
\text { Arising From Severe } \\
\text { Adverse Selection }\end{array}$} \\
\hline & $\begin{array}{l}\text { Females } \\
\%\end{array}$ & $\begin{array}{l}\text { Males } \\
\%\end{array}$ & $\begin{array}{l}\text { Females } \\
\%\end{array}$ & $\begin{array}{l}\text { Males } \\
\%\end{array}$ & $\begin{array}{l}\text { Females } \\
\%\end{array}$ & $\begin{array}{l}\text { Males } \\
\%\end{array}$ \\
\hline Large & 0.069 & 0.064 & 0.034 & 0.032 & 0.066 & 0.062 \\
\hline Small & 0.057 & 0.051 & 0.055 & 0.051 & 0.350 & 0.308 \\
\hline
\end{tabular}

(a) The worst case under a moratorium on genetic test results, in the smaller market, would be premium increases of about $0.05 \%$ or $0.1 \%$, depending on the stage at which a claim would be payable. Of course this is much larger than before, but as an extreme upper limit it is very modest.

(b) With a moratorium on family history, premiums in the smaller market could increase by as much as $0.35 \%$ because of adverse selection. This is because persons at risk because of a family history can buy insurance at the new standard rates and are assumed to do so at rate 0.25 per annum, which is so high that not many are tested before buying insurance. When family history underwriting is allowed, an adverse test result is a prerequisite for adverse selection to occur.

Any of these numbers could be increased if adverse selection extended to sums assured higher than average, in proportion to the excess. However we believe that

Table 10. Percentage increases in standard premium rates for CI insurance arising from new underwriting classes, and in all premiums arising from moderate or severe adverse selection, following a moratorium on the use of all genetic test results and family history. CI market operating between ages 20 and 60. Claims arising at Stage 3 of Harper's progression.

\begin{tabular}{|c|c|c|c|c|c|c|}
\hline \multirow[b]{2}{*}{$\begin{array}{l}\text { Size of } \\
\text { Market }\end{array}$} & \multicolumn{2}{|c|}{$\begin{array}{l}\text { OR Premium Increases } \\
\text { Arising From New } \\
\text { Underwriting Classes }\end{array}$} & \multicolumn{2}{|c|}{$\begin{array}{l}\text { Premium Increases } \\
\text { Arising From Moderate } \\
\text { Adverse Selection }\end{array}$} & \multicolumn{2}{|c|}{$\begin{array}{l}\text { Premium Increases } \\
\text { Arising From Severe } \\
\text { Adverse Selection }\end{array}$} \\
\hline & $\begin{array}{l}\text { Females } \\
\%\end{array}$ & $\begin{array}{l}\text { Males } \\
\%\end{array}$ & $\begin{array}{l}\text { Females } \\
\%\end{array}$ & $\begin{array}{l}\text { Males } \\
\%\end{array}$ & $\begin{array}{l}\text { Females } \\
\%\end{array}$ & $\begin{array}{l}\text { Males } \\
\%\end{array}$ \\
\hline Large & 0.038 & 0.035 & 0.021 & 0.019 & 0.041 & 0.039 \\
\hline Small & 0.030 & 0.026 & 0.031 & 0.028 & 0.225 & 0.207 \\
\hline
\end{tabular}


Table 11. Percentage increases in CI insurance premium rates arising from severe adverse selection. Moratoria on the use of genetic test results, family history underwriting still allowed. CI market operating between ages 20 and 60. Claims arising at Stage 2 of Harper's progression.

\begin{tabular}{|c|c|c|c|c|c|c|c|}
\hline \multirow[b]{3}{*}{$\begin{array}{l}\text { Size of } \\
\text { Market }\end{array}$} & \multirow[b]{3}{*}{$\begin{array}{l}\text { Insurance Purchasing of } \\
\text { At-Risk Individuals }\end{array}$} & \multirow[b]{3}{*}{$\begin{array}{l}\text { Rate of } \\
\text { Testing }\end{array}$} & \multirow[b]{3}{*}{$\begin{array}{l}\text { Age Range } \\
\text { of Testing }\end{array}$} & \multicolumn{4}{|c|}{ Moratorium on Using } \\
\hline & & & & \multicolumn{2}{|c|}{ All test results } & \multicolumn{2}{|c|}{$\begin{array}{l}\text { Adverse test } \\
\text { results }\end{array}$} \\
\hline & & & & $\begin{array}{l}\text { Females } \\
\%\end{array}$ & $\begin{array}{l}\text { Males } \\
\%\end{array}$ & $\begin{array}{l}\text { Females } \\
\%\end{array}$ & $\begin{array}{l}\text { Males } \\
\%\end{array}$ \\
\hline \multirow[t]{3}{*}{ Large } & Normal & 0.035 & $20-40$ & 0.011 & 0.011 & 0.010 & 0.010 \\
\hline & Half & 0.035 & $20-40$ & 0.018 & 0.017 & 0.016 & 0.015 \\
\hline & Nil & 0.035 & $20-40$ & 0.029 & 0.027 & 0.025 & 0.024 \\
\hline Small & $\mathrm{Ni}$ & 0.035 & $20-40$ & 0.090 & 0.082 & 0.078 & 0.071 \\
\hline
\end{tabular}

they show that only in the most extreme circumstances could adverse selection in respect of HD alone have any impact on a $\mathrm{CI}$ insurance market of any reasonable size.

\section{A LIFE INSURANCE MODEL}

Fig. 6 shows a semi-Markov model of a life insurance market, similar to that in Gui $\&$ Macdonald (2002). The intensities $\mu_{x+t, d}^{i 46}$ and $\mu_{x+t, d}^{i 56}$, representing post-onset mortality, depend on both age and duration. In fact the mortality rates in Section 2 depend on duration alone, but Wilkie (2000) pointed out that a duration-dependent post-onset rate of mortality may be lower than the usual age-related rate of mortality,

Table 12. Percentage increases in CI insurance premium rates arising from severe adverse selection. Moratoria on the use of genetic test results, family history underwriting still allowed. CI market operating between ages 20 and 60. Claims arising at Stage 3 of Harper's progression.

\begin{tabular}{|c|c|c|c|c|c|c|c|}
\hline \multirow[b]{3}{*}{$\begin{array}{l}\text { Size of } \\
\text { Market }\end{array}$} & \multirow[b]{3}{*}{$\begin{array}{l}\text { Insurance Purchasing of } \\
\text { At-Risk Individuals }\end{array}$} & \multirow[b]{3}{*}{$\begin{array}{l}\text { Rate of } \\
\text { Testing }\end{array}$} & \multirow[b]{3}{*}{$\begin{array}{l}\text { Age Range } \\
\text { of Testing }\end{array}$} & \multicolumn{4}{|c|}{ Moratorium on Using } \\
\hline & & & & \multicolumn{2}{|c|}{ All test results } & \multicolumn{2}{|c|}{$\begin{array}{l}\text { Adverse test } \\
\text { results }\end{array}$} \\
\hline & & & & $\begin{array}{l}\text { Females } \\
\%\end{array}$ & $\begin{array}{l}\text { Males } \\
\%\end{array}$ & $\begin{array}{l}\text { Females } \\
\%\end{array}$ & $\begin{array}{l}\text { Males } \\
\%\end{array}$ \\
\hline \multirow[t]{3}{*}{ Large } & Normal & 0.035 & $20-40$ & 0.007 & 0.006 & 0.006 & 0.006 \\
\hline & Half & 0.035 & $20-40$ & 0.010 & 0.010 & 0.009 & 0.009 \\
\hline & Nil & 0.035 & $20-40$ & 0.016 & 0.015 & 0.014 & 0.013 \\
\hline Small & Nil & 0.035 & $20-40$ & 0.049 & 0.045 & 0.042 & 0.039 \\
\hline
\end{tabular}




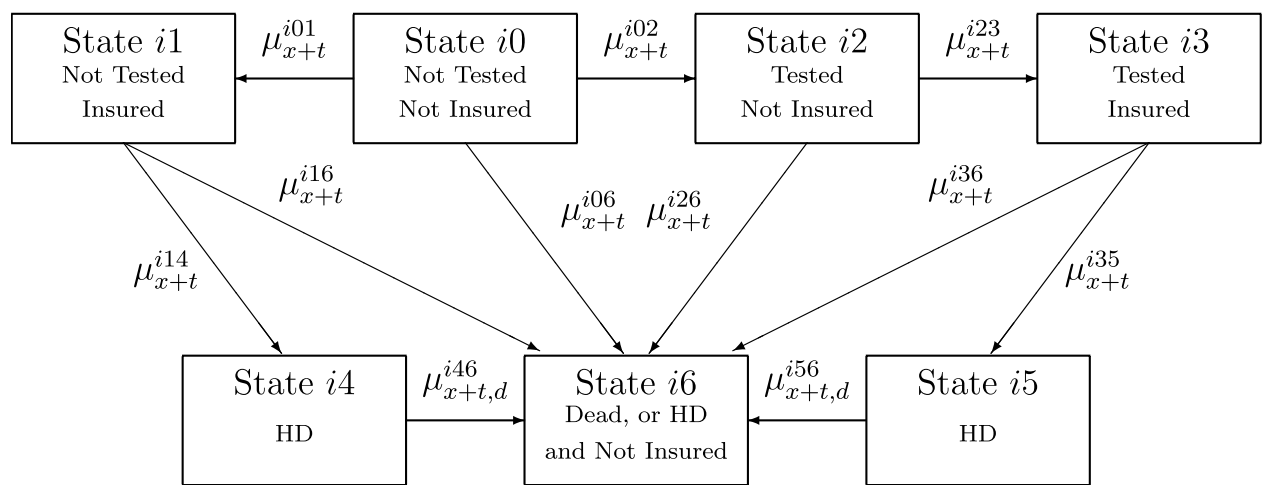

Fig. 6. A semi-Markov model of insurance purchase and life insurance events for a person with genotype $g_{i}$.

especially at high ages. We therefore take these intensities to be the greater of those based on Eqs. (2) to (4) (as appropriate) or those of English Life Tables No. 15.

State $i 6$ is labelled 'Dead, or HD and Not Insured'. If an uninsured person develops symptoms of $\mathrm{HD}$, they become uninsurable, so for simplicity we represent this by transition into the only absorbing state in the model.

It is necessary to have separate states representing onset of HD from tested and untested insured states, because:

(a) they could be in different underwriting classes, therefore contributing to the calculation of different premium rates when we model adverse selection (Section 8); and

(b) part of adverse selection after receiving an adverse test result could be to take out a larger sum assured.

Although the model is semi-Markov, EPVs can be calculated in a Markov framework, hence Thiele's equations can be used, in the same way as described in Section 3.3.

\section{LIFE INSURANCE UNDERWRITING}

7.1. Underwriting with known CAG repeat length: 40-50 CAG repeats

We can write down the EPVs of a unit sum assured and a unit annual premium payable continuously while alive, between ages $x$ and $x+n$, for a person with genotype $g_{i}$ :

$\mathrm{EPV}[$ Benefit $]=\int_{0}^{n} e^{-\delta t} \int_{0}^{t}{ }_{s} p_{x}^{i 00} \mu_{x+s \quad t-s}^{i 01} p_{x+s, 0}^{i 11} \mu_{x+t, t-s}^{i 12} d s d t$ 
$\mathrm{EPV}[$ Premium $]=\int_{0}^{n} e^{-\delta t}\left({ }_{t} p_{x}^{i 00}+\int_{0}^{t}{ }_{s} p_{x}^{i 00} \mu_{x+s t-s}^{i 01} p_{x+s, 0}^{i 11} d s\right) d t$.

Alternatively, we can obtain these EPVs from the solutions of Thiele's equations in respect of the insured states in the model shown in Fig. 6 (extended appropriately to different genotypes as in Fig. 5).

Table 13 shows level premiums for a level amount of life insurance, expressed as a percentage of the premium for standard risks.

\subsection{Underwriting with known CAG repeat length: 36-39 CAG repeats}

Table 14 shows level premiums for a level amount of life insurance, expressed as a percentage of the premium for standard risks, given 36-39 CAG repeats. The highest is $117 \%$, for a female age 30 seeking 30 years' cover. This table suggests that people with intermediate alleles might be offered life insurance at standard rates in all cases.

\subsection{Underwriting based on family history only}

Brackenridge \& Elder (1998) provide guidelines for the selection of risks and premium ratings given a priori genetic risk of $50 \%$. A summary of the guidelines on the basis of family risk but not genetic testing is presented in Table 15 . They can be modified if the last forbear known to be heterozygous was a grandparent, implying a genetic risk of $25 \%$, or a great-grandparent, giving a genetic risk of $12.5 \%$. We have included in the table, for comparison, the resulting premiums as a percentage of standard rates, for males.

The guidelines in Brackenridge \& Elder (1998) in the case that a genetic test result is available are based on the earlier tests for markers, not direct analysis of the HD gene; their references are Gusella et al. (1983) and Brock et al. (1989). They are therefore based on an assessment of the risk of heterozygosity, given an adverse test result, that is now out of date. Brackenridge \& Elder (1998) is without doubt the authority on medical underwriting, so this is an interesting sign of the great speed at which medical genetics is developing.

Smith (1998) gave sample extra premiums for term and endowment assurances, for mutation carriers and (by a simple Bayesian argument) for asymptomatic at-risk individuals. The latter were insurable at all ages and terms, sometimes with only a modest extra premium; the former were not always insurable, assuming a $400 \%$ extra premium limit. An example in respect of term assurance is shown in Table 16. Under endowment assurances, coverage could always be offered, at an extra premium not exceeding about $40 \%$. Overall, Smith's conclusions were that life insurance could be provided to people at risk of $\mathrm{HD}$, or even sometimes to mutation carriers, at lower cost than had often previously been assumed (as exemplified by five different underwriting manuals). 
Table 13. Level net premium for level life insurance cover for persons with a known HD mutation, with 40-50 CAG repeats, as a percentage of the premium for standard risks.

\begin{tabular}{|c|c|c|c|c|c|c|c|c|c|c|c|c|c|}
\hline \multirow[b]{2}{*}{ Sex of Applicant } & \multirow[b]{2}{*}{$\begin{array}{l}\text { Age at Entry } \\
\text { (Years) }\end{array}$} & \multirow[b]{2}{*}{$\begin{array}{l}\text { Policy Term } \\
\text { (Years) }\end{array}$} & \multicolumn{11}{|c|}{ Number of CAG Repeats } \\
\hline & & & $\begin{array}{l}40 \\
\%\end{array}$ & $\begin{array}{l}41 \\
\%\end{array}$ & $\begin{array}{l}42 \\
\%\end{array}$ & $\begin{array}{l}43 \\
\%\end{array}$ & $\begin{array}{l}44 \\
\%\end{array}$ & $\begin{array}{l}45 \\
\%\end{array}$ & $\begin{array}{l}46 \\
\%\end{array}$ & $\begin{array}{l}47 \\
\%\end{array}$ & $\begin{array}{l}48 \\
\%\end{array}$ & $\begin{array}{l}49 \\
\%\end{array}$ & $\begin{array}{l}50 \\
\%\end{array}$ \\
\hline \multirow[t]{10}{*}{ Female } & \multirow[t]{4}{*}{20} & 10 & 100 & 100 & 100 & 102 & 105 & 114 & 132 & 166 & 219 & 293 & 387 \\
\hline & & 20 & 101 & 105 & 117 & 147 & 209 & 315 & 475 & 690 & 951 & 1,242 & 1,545 \\
\hline & & 30 & 112 & 138 & 192 & 288 & 432 & 624 & 853 & 1,107 & 1,371 & 1,631 & 1,877 \\
\hline & & 40 & 141 & 192 & 272 & 381 & 513 & 664 & 825 & 990 & 1,154 & 1,310 & 1,456 \\
\hline & \multirow[t]{3}{*}{30} & 10 & 101 & 106 & 117 & 139 & 175 & 225 & 285 & 349 & 414 & 477 & 535 \\
\hline & & 20 & 116 & 146 & 208 & 307 & 438 & 588 & 741 & 885 & 1,014 & 1,125 & 1,220 \\
\hline & & 30 & 147 & 206 & 294 & 408 & 535 & 662 & 780 & 884 & 972 & 1,044 & 1,104 \\
\hline & \multirow[t]{2}{*}{40} & 10 & 106 & 114 & 126 & 141 & 158 & 174 & 190 & 205 & 219 & 231 & 242 \\
\hline & & 20 & 142 & 181 & 229 & 279 & 326 & 366 & 401 & 430 & 454 & 474 & 491 \\
\hline & 50 & 10 & 108 & 114 & 120 & 126 & 132 & 137 & 142 & 147 & 151 & 155 & 158 \\
\hline \multirow[t]{10}{*}{ Male } & \multirow[t]{4}{*}{20} & 10 & 100 & 100 & 100 & 101 & 102 & 105 & 111 & 123 & 142 & 169 & 203 \\
\hline & & 20 & 101 & 102 & 108 & 121 & 148 & 196 & 269 & 367 & 487 & 621 & 760 \\
\hline & & 30 & 106 & 118 & 146 & 195 & 270 & 369 & 490 & 624 & 764 & 902 & 1,032 \\
\hline & & 40 & 119 & 144 & 186 & 244 & 316 & 399 & 488 & 581 & 672 & 760 & 842 \\
\hline & \multirow[t]{3}{*}{30} & 10 & 101 & 103 & 108 & 120 & 139 & 165 & 196 & 230 & 264 & 298 & 329 \\
\hline & & 20 & 109 & 126 & 161 & 219 & 295 & 384 & 475 & 561 & 638 & 705 & 762 \\
\hline & & 30 & 124 & 155 & 205 & 270 & 344 & 419 & 490 & 552 & 604 & 648 & 684 \\
\hline & \multirow{2}{*}{40} & 10 & 103 & 107 & 113 & 121 & 130 & 138 & 147 & 155 & 163 & 170 & 176 \\
\hline & & 20 & 120 & 140 & 165 & 192 & 218 & 241 & 261 & 278 & 292 & 304 & 314 \\
\hline & 50 & 10 & 102 & 104 & 106 & 108 & 109 & 111 & 113 & 114 & 116 & 117 & 119 \\
\hline
\end{tabular}


Table 14. Level net premium for level life insurance cover for persons with a known 'intermediate allele' HD mutation, as a percentage of the premium for standard risks.

\begin{tabular}{|c|c|c|c|c|c|c|c|c|c|}
\hline \multirow[b]{3}{*}{$\begin{array}{l}\text { Age at Entry } \\
\text { (Years) }\end{array}$} & \multirow[b]{3}{*}{$\begin{array}{l}\text { Policy Term } \\
\text { (Years) }\end{array}$} & \multicolumn{8}{|c|}{ Premium as Percentage of Standard } \\
\hline & & \multicolumn{4}{|c|}{$\begin{array}{l}\text { Females } \\
\text { No. of CAG Repeats }\end{array}$} & \multicolumn{4}{|c|}{$\begin{array}{l}\text { Males } \\
\text { No. of CAG Repeats }\end{array}$} \\
\hline & & $\begin{array}{l}36 \\
\%\end{array}$ & $\begin{array}{l}37 \\
\%\end{array}$ & $\begin{array}{l}38 \\
\%\end{array}$ & $\begin{array}{l}39 \\
\%\end{array}$ & $\begin{array}{l}36 \\
\%\end{array}$ & $\begin{array}{l}37 \\
\%\end{array}$ & $\begin{array}{l}38 \\
\%\end{array}$ & $\begin{array}{l}39 \\
\%\end{array}$ \\
\hline \multirow[t]{4}{*}{20} & 10 & 100 & 100 & 100 & 100 & 100 & 100 & 100 & 100 \\
\hline & 20 & 100 & 100 & 100 & 100 & 100 & 100 & 100 & 100 \\
\hline & 30 & 100 & 100 & 101 & 103 & 100 & 100 & 100 & 101 \\
\hline & 40 & 100 & 101 & 104 & 114 & 100 & 100 & 101 & 106 \\
\hline \multirow[t]{3}{*}{30} & 10 & 100 & 100 & 100 & 100 & 100 & 100 & 100 & 100 \\
\hline & 20 & 100 & 100 & 101 & 104 & 100 & 100 & 100 & 102 \\
\hline & 30 & 100 & 101 & 104 & 117 & 100 & 100 & 102 & 108 \\
\hline \multirow[t]{2}{*}{40} & 10 & 100 & 100 & 100 & 102 & 100 & 100 & 100 & 101 \\
\hline & 20 & 100 & 101 & 104 & 116 & 100 & 100 & 102 & 108 \\
\hline 50 & 10 & 100 & 100 & 101 & 104 & 100 & 100 & 100 & 101 \\
\hline
\end{tabular}

Table 17 shows level premiums for a level amount of life insurance, expressed as a percentage of the premium for standard risks, in respect of an applicant with an affected parent or sibling. These were calculated in the same way as the CI insurance premiums in Section 4.3.

(a) They are broadly consistent with the results in Table 16 from Smith (1998) (note that these were expressed as percentage extra premiums).

(b) As with CI insurance premiums, they are sometimes (younger lives, up to 45 CAG repeats) higher than the premiums based on a genetic test result.

(c) They are very much lower than the premiums implied by the suggested ratings in Brackenridge \& Elder (1998) (Table 15).

Table 15. Guidelines for rating the risk of Huntington's disease in life insurance, on the basis of family risk but not genetic testing. Source: Brackenridge \& Elder (1998).

\begin{tabular}{lll}
\hline & & $\begin{array}{l}\text { Premium (male) as Percentage of } \\
\text { Standard Rates } \\
\%\end{array}$ \\
Information in Proposal & Suggested Rating & $\mathrm{n} / \mathrm{a}$ \\
\hline Symptoms present & Uninsurable & $\mathrm{n} / \mathrm{a}$ \\
Age under 21 & Decline & 901 (age 21) \\
Age 21-35 & +7 per mille for 10 years & 378 (age 36) \\
Age 36-45 & +5 per mille for 10 years & 202 (age 46) \\
Age 46-55 & +5 per mille until age 55 & \\
Age 56 and over & Standard & \\
\hline
\end{tabular}


Table 16. Examples of percentage extra premiums for term assurance, for a male with an affected father. Source: Smith (1998).

\begin{tabular}{lllll}
\hline & Mutation Carrier & & \multicolumn{2}{l}{ Asymptomatic At-Risk } \\
Age & Term $\leqslant 10$ Yrs & Term $>10$ Yrs & Term $\leqslant 10$ Yrs & Term $>10$ Yrs \\
\hline$<35$ & $+325 \%$ & Decline & $+125 \%$ & $+200 \%$ \\
$35-45$ & $+175 \%$ & $+275 \%$ & $+50 \%$ & $+75 \%$ \\
$45-55$ & $+50 \%$ & $+100 \%$ & Standard & Standard \\
$>55$ & Standard & $+25 \%$ & Standard & Standard \\
\hline
\end{tabular}

\section{LIFE INSURANCE AND ADVERSE SELECTION}

\subsection{A model of the life insurance market}

Fig. 6 shows a model of a life insurance market, for a person with genotype $g_{i}$. We would like to use this to illustrate the potential costs of adverse selection, as we did for CI insurance in Section 5.1. In Section 5.1, the premium rate payable by an insured person at age $x+t$ was given by Eq. (7). Here we must allow for the durationdependent survival rates after onset. For simplicity, suppose that genotype $g_{i}$ by itself is an underwriting class. The rate of premium we want is that which would be charged in the absence of adverse selection, so assume there is no genetic testing $\left(\mu_{x+t}^{i 02}=0\right)$. Then the weighted average intensity into the dead state from the two insured states $i 1$ and $i 4$, denoted $\mu_{x+t}^{\mathscr{q}}$, is:

$\mu_{x+t}^{\mathscr{C}}=\frac{{ }_{t} p_{x}^{i 01} \mu_{x+t}^{i 16}+\int_{0}^{t}{ }_{t, z} p_{x}^{i 04} \mu_{x+t, z}^{i 46} d z}{{ }_{t}^{i 01}+\int_{0}^{t}{ }_{t, z} p_{x}^{i 04} d z}$.

Table 17. Level net premiums for level life insurance cover as percentage of the level premium for standard risks, for persons with a family history of HD (affected parent or sibling).

\begin{tabular}{llll}
\hline $\begin{array}{l}\text { Age at Entry } \\
\text { (Years) }\end{array}$ & $\begin{array}{l}\text { Policy Term } \\
\text { (Years) }\end{array}$ & $\begin{array}{l}\text { Females } \\
\%\end{array}$ & $\begin{array}{l}\text { Males } \\
\%\end{array}$ \\
\hline 20 & 10 & 114 & 105 \\
& 20 & 211 & 150 \\
& 30 & 297 & 202 \\
30 & 40 & 293 & 203 \\
& 10 & 122 & 112 \\
40 & 20 & 187 & 151 \\
50 & 30 & 208 & 160 \\
& 10 & 107 & 103 \\
& 20 & 130 & 115 \\
& 10 & 102 & 101 \\
\hline
\end{tabular}


Table 18. Percentage increases in premium rates for life insurance arising from moderate adverse selection. Moratoria on the use of genetic test results, family history underwriting still allowed. Life insurance market operating between ages 20 and 60.

\begin{tabular}{|c|c|c|c|c|c|c|c|}
\hline \multirow[b]{3}{*}{$\begin{array}{l}\text { Size of } \\
\text { Market }\end{array}$} & \multirow[b]{3}{*}{$\begin{array}{l}\text { Insurance Purchasing of } \\
\text { At-Risk Individuals }\end{array}$} & \multirow[b]{3}{*}{$\begin{array}{l}\text { Rate of } \\
\text { Testing }\end{array}$} & \multirow[b]{3}{*}{$\begin{array}{l}\text { Age Range } \\
\text { of Testing }\end{array}$} & \multicolumn{4}{|c|}{ Moratorium on Using } \\
\hline & & & & \multicolumn{2}{|c|}{ All test results } & \multicolumn{2}{|c|}{$\begin{array}{l}\text { Adverse test } \\
\text { results }\end{array}$} \\
\hline & & & & $\begin{array}{l}\text { Females } \\
\%\end{array}$ & $\begin{array}{l}\text { Males } \\
\%\end{array}$ & $\begin{array}{l}\text { Females } \\
\%\end{array}$ & $\begin{array}{l}\text { Males } \\
\%\end{array}$ \\
\hline \multirow[t]{3}{*}{ Large } & Normal & 0.014 & $20-40$ & 0.001 & 0.001 & 0.001 & 0.001 \\
\hline & Half & 0.014 & $20-40$ & 0.002 & 0.001 & 0.002 & 0.001 \\
\hline & Nil & 0.014 & $20-40$ & 0.004 & 0.002 & 0.004 & 0.002 \\
\hline Small & Nil & 0.014 & $20-40$ & 0.003 & 0.002 & 0.003 & 0.002 \\
\hline \multirow[t]{3}{*}{ Large } & Normal & 0.014 & $20-60$ & 0.001 & 0.001 & 0.001 & 0.001 \\
\hline & Half & 0.014 & $20-60$ & 0.002 & 0.001 & 0.002 & 0.001 \\
\hline & Nil & 0.014 & $20-60$ & 0.004 & 0.002 & 0.004 & 0.002 \\
\hline Small & Nil & 0.014 & $20-60$ & 0.003 & 0.002 & 0.002 & 0.001 \\
\hline \multirow[t]{3}{*}{ Large } & Normal & 0.035 & $20-40$ & 0.003 & 0.002 & 0.003 & 0.001 \\
\hline & Half & 0.035 & $20-40$ & 0.006 & 0.003 & 0.005 & 0.003 \\
\hline & Nil & 0.035 & $20-40$ & 0.010 & 0.005 & 0.008 & 0.004 \\
\hline Small & Nil & 0.035 & $20-40$ & 0.008 & 0.004 & 0.005 & 0.003 \\
\hline
\end{tabular}

The superscript ' $\mathscr{C}$ ' in $\mu_{x+t}^{\mathscr{C}}$ indicates that this is a rate in respect of an underwriting class; if genotypes are combined into underwriting classes, we would extend the weighted average accordingly as in Eq. (7). These are the rates of premium we use when adverse selection is introduced, because they are the rates an insurer would use in a 'normal' market.

We use the same device as in Section 3.3 to bring the calculations back within a Markov framework, by 'paying' a 'sum assured' equal to the policy value on entering an HD state from an insured state. The statewise policy value ${ }_{t, 0} V_{x}^{i 4}$ (and likewise

Table 19. Percentage increases in standard premium rates for life insurance arising from new underwriting classes, and in all premiums arising from moderate or severe adverse selection, following a moratorium on the use of all genetic test results and family history. Life insurance market operating between ages 20 and 60.

\begin{tabular}{|c|c|c|c|c|c|c|}
\hline \multirow[b]{2}{*}{ Size of Market } & \multicolumn{2}{|c|}{$\begin{array}{l}\text { OR Premium Increases } \\
\text { Arising From New } \\
\text { Underwriting Classes }\end{array}$} & \multicolumn{2}{|c|}{$\begin{array}{l}\text { Premium Increases } \\
\text { Arising From Moderate } \\
\text { Adverse Selection }\end{array}$} & \multicolumn{2}{|c|}{$\begin{array}{l}\text { Premium Increases } \\
\text { Arising From Severe } \\
\text { Adverse Selection }\end{array}$} \\
\hline & $\begin{array}{l}\text { Females } \\
\%\end{array}$ & $\begin{array}{l}\text { Males } \\
\%\end{array}$ & $\begin{array}{l}\text { Females } \\
\%\end{array}$ & $\begin{array}{l}\text { Males } \\
\%\end{array}$ & $\begin{array}{l}\text { Females } \\
\%\end{array}$ & $\begin{array}{l}\text { Males } \\
\%\end{array}$ \\
\hline Large & 0.042 & 0.022 & 0.024 & 0.014 & 0.049 & 0.029 \\
\hline Small & 0.032 & 0.015 & 0.032 & 0.018 & 0.256 & 0.148 \\
\hline
\end{tabular}


Table 20. Percentage increases in premium rates for life insurance arising from severe adverse selection. Moratoria on the use of genetic test results, family history underwriting still allowed. Life insurance market operating between ages 20 and 60 .

\begin{tabular}{|c|c|c|c|c|c|c|c|}
\hline \multirow[b]{3}{*}{$\begin{array}{l}\text { Size of } \\
\text { Market }\end{array}$} & \multirow{3}{*}{$\begin{array}{l}\text { Insurance } \\
\text { Purchasing } \\
\text { of At-Risk } \\
\text { Individuals }\end{array}$} & \multirow[b]{3}{*}{$\begin{array}{l}\text { Rate of } \\
\text { Testing }\end{array}$} & \multirow[b]{3}{*}{$\begin{array}{l}\text { Age Range } \\
\text { of Testing }\end{array}$} & \multicolumn{4}{|c|}{ Moratorium on Using } \\
\hline & & & & \multicolumn{2}{|c|}{ All test results } & \multicolumn{2}{|c|}{ Adverse test results } \\
\hline & & & & $\begin{array}{l}\text { Females } \\
\%\end{array}$ & $\begin{array}{l}\text { Males } \\
\%\end{array}$ & $\begin{array}{l}\text { Females } \\
\%\end{array}$ & $\begin{array}{l}\text { Males } \\
\%\end{array}$ \\
\hline \multirow[t]{3}{*}{ Large } & Normal & 0.035 & $20-40$ & 0.008 & 0.004 & 0.007 & 0.004 \\
\hline & Half & 0.035 & $20-40$ & 0.011 & 0.006 & 0.010 & 0.006 \\
\hline & Nil & 0.035 & $20-40$ & 0.016 & 0.009 & 0.014 & 0.008 \\
\hline Small & Nil & 0.035 & $20-40$ & 0.050 & 0.028 & 0.043 & 0.024 \\
\hline
\end{tabular}

$\left.{ }_{t, 0} V_{x}^{i 5}\right)$, for policy term $n$ years and sum assured $£ 1$, is:

${ }_{t, 0} V_{x}^{i 4}=\int_{0}^{n-t} e^{-\delta s}{ }_{s} p_{x+t, 0}^{i 44}\left(\mu_{x+t+s, s}^{i 46}-\mu_{x+t+s}^{\mathscr{C}}\right) d s$.

\subsection{Parameterisation}

The parameterisation of the model, in respect of insurance purchase and genetic testing, is exactly the same as in Section 5.2. Recall that 'moderate' adverse selection means insurance is purchased at twice the 'normal' rate, and 'severe' adverse selection means that the rate of purchase is 0.25 per annum. Clearly, we might regard the larger market as more relevant for life insurance.

\subsection{Moratoria on genetic test results}

Table 18 shows the percentage increases in premium rates arising from moderate adverse selection, under moratoria covering genetic test results but not family history. They can truly be described as negligible; the insurer who can calculate a premium to an accuracy of $0.01 \%$, which is the largest cost in the table, does not exist. Nevertheless we should hesitate to say that adverse selection in respect of genetic disorders in toto is negligible, as HD is just one (admittedly severe) disorder among several.

\subsection{Moratoria on family history and genetic test results}

Table 19 shows the percentage increases in standard premium rates arising from the creation of a single underwriting class, and in all premiums arising from moderate or severe adverse selection (parameterised as in Section 5.4), following a moratorium on the use of all genetic test results and family history. The premium increases are now 
larger but hardly more significant, up to about $0.04 \%$, even if there were no adverse selection, and over $0.06 \%$ if there was (for females).

\subsection{More extreme adverse selection}

As for CI insurance, we show in Table 20 the effect of severe adverse selection and the higher rate of genetic testing on the costs under moratoria on genetic test results. The costs under a moratorium on family history were included in Table 19. These support our previous conclusion: only in the most extreme (and unlikely) circumstances, and in the smaller market, would these costs even be discernable.

\section{CONCLUSIONS}

\subsection{Critical illness insurance}

The definition of onset in Brinkman et al. (1997) is based on the earliest indications of HD, whereas a CI claim is likely to arise some time later. Harper (1996) provides a detailed description of three stages of HD, each corresponding roughly to 5 years within an overall 15-year survival. This suggested an accelerated lifetime model, applied to the post-onset survival rates, to represent claim payments on entering Stage 2 or Stage 3 of Harper's progression. These were used in the CI insurance model from Gutiérrez \& Macdonald (2001). We found the following:

(a) CI premium rates, as a proportion of standard rates, varied greatly with age and policy term, as well as CAG repeat length. There were quite large differences between males and females. In many cases the premiums fell within the limits currently regarded as insurable by UK companies.

(b) In all cases persons with an 'intermediate' allele (36-39 CAG repeats) could be offered CI cover, mostly at standard rates. In practice such test results might be ignored.

(c) Premiums based on family history alone (affected parent or sibling) fell naturally in the range of those for individual CAG repeat lengths, with the following features:

(1) If a CI claim corresponded to Stage 3 in Harper's progression, CI cover could be offered in all cases, though younger persons would be near the limit of current UK underwriting practice.

(2) Level premiums dropped sharply for older persons (over 40), leading to a possible lapse and re-entry risk.

(3) A younger person, carrying a mutation with a low CAG repeat number, could often be offered a premium lower than that based on family history, but under most moratoria this would require the insurer to underwrite on the basis of a disclosed adverse test result, which would be disallowed.

(4) For high CAG repeat numbers, premiums for 10 -year policies were very much higher than standard. This showed that it could be quite misleading 
to treat the delay between onset and claiming in a deterministic way, for example by assuming that claims were paid 10 years after onset.

(d) The potential costs of adverse selection were very small, because of the rarity of HD mutations. In absolute terms they appeared negligible, but of course this is only one genetic disorder among several. If family history underwriting was still allowed, premium increases did not exceed $0.1 \%$ even assuming a rather high rate of genetic testing and extreme adverse selection. Only in a much smaller market than we assumed, or if adverse selection included gross over-insurance, would premiums be affected noticeably. A moratorium on the use of family history would increase premiums by much more even in the absence of adverse selection, but the absolute increases are still very small.

\subsection{Life insurance}

Our conclusions in respect of life insurance are very much along the same lines as those in respect of CI insurance, and we shall avoid repetition. We found premiums to be affordable in many cases, either with a relatively low number of CAG repeats or just with a family history. The results in the latter case were broadly consistent with those of Smith (1998) and much lower than the ratings in Brackenridge \& Elder (1998). Premiums given any intermediate allele, even 39 CAG repeats, were close to standard rates, and such test results could perhaps be ignored for life insurance. The potential costs of adverse selection arising from HD alone were negligible, but until we can place this in the context of all single-gene disorders we cannot draw firm conclusions.

It is interesting to compare the life insurance premiums given a family history of HD with the premiums given a family history of another neurological genetic disorder, early-onset Alzheimer's disease (EOAD), associated with Presenilin-1 gene mutations, given in Gui \& Macdonald (2002). In many cases the premiums in respect of HD are lower than those in respect of EOAD. The reason is that mortality after onset of HD is considerably lighter than mortality after onset of EOAD associated with Presenilin-1 mutations (or more accurately, the available estimates suggest that this is so). HD might spring to mind as the prototype of a severe, single-gene disorder, but age at onset is only half of the story.

\subsection{Variable single-gene disorders: a problem for a moratorium?}

This is the first study to consider insurance pricing in the presence of a variable disease-causing mutation. Previous studies, including Smith (1998) but also all studies into other genetic disorders, have assumed that all mutations in each gene involved have the same penetrance.

Classifying people as either mutation carriers or non-carriers, hence the crisp dichotomy of 'adverse' and 'clear' genetic test results, is perhaps consistent with the simplified view of genetic disorders as homogeneous, but is not consistent with genuine variability or heterogeneity. DNA-based genetic testing (if reliable) is more accurate than family history information, in the sense that it resolves the uncertainly 
in the latter, but that does not mean that any such ranking may be assumed when considering the medical or financial consequences. The examples given here of premium ratings given an 'adverse' test result that are much lower than those based on the family history show this clearly.

This ambiguity could affect the definition of an adverse test result in any moratorium that allows family history to be used to underwrite. There seems to be broad agreement in the UK industry that a clear test result will, in practice, be taken into account however a moratorium is worded. We included this possibility in our models, finding that the premiums charged to those who remain with a family history rise, with the removal of some non-carriers from this particular risk pool. What might happen were we to extend this, seemingly reasonable, process to a variable genetic disorder such as HD? First, those with test results showing a small number of CAG repeats could, in some cases, disclose them to get lower premiums than those based on their family history, so the latter would have to rise, perhaps uncovering another group of mutation carriers who could get lower premiums by disclosing test results, and so on until the limits of insurability were reached. Thus common sense and the best of intentions could lead to the use of adverse genetic tests in underwriting.

One response would be to interpret a moratorium more strictly, and impose a family history rating regardless of the disclosure of a clear or 'mildly' adverse test result. How then should we respond to the applicant who has no mutation, or a mutation with 'only' 40 CAG repeats? To ignore the fact would be to tell him or her that as a member of a family at risk of HD they have a duty to pool their risks with those of all members of all other such families, regardless of their personal circumstances. The burden is theirs, not to be shared with those at risk of other single-gene disorders (who will presumably bear their own burdens), or of mutifactorial disorders, or of anything else. In passing, we note that our suggestion that most carriers of 'intermediate' HD alleles (36-39 CAG repeats) might be offered standard premium rates, while it seems sensible, is in fact a step in the direction of using adverse test results to underwrite. Once the principle is allowed for clear test results, where should we stop? It will be interesting to see how the implications of a moratorium are worked out as more is learned about heterogeneity and variability of single-gene disorders.

\subsection{Disclosure for pricing versus disclosure for risk management}

This paper shows that complex questions of insurance management can emerge even from consideration of rare, single-gene disorders. Premium rating is only one among several such questions. Fears about discrimination have led insurers to accept, or regulators to impose, moratoria on the use of genetic information for premium rating. It seems that most moratoria in practice have gone further than this, and ban the disclosure of the relevant information. In the UK, this stems partly from the principles underlying data protection: since the insurer will not use the information for pricing, they should not ask for it. Of course this provides strong reassurance that 
it will not be used in pricing, but it also stops the insurer from using it in other aspects of risk management that would in no way disadvantage those at risk, and might strengthen the overall position of the insurance pool. For example if a group of insurers entered into a pooling arrangement to share the costs of subsidising premiums for at-risk applicants, they would need to know how to share the costs and how to reserve for the liability. Indeed the regulator might require this of them.

Public trust in the insurance industry is lacking, sometimes with good reason. Understandably, therefore, it is disclosure, rather than particular uses, of genetic information that has been restricted at first. And although actuarial research into genetic disorders is far from complete, studies such as this one indicate that the risks in absolute terms are so small that this might not matter. This should not obscure the important point of principle, however: if government or society wishes to guarantee access to insurance, there will come a point when it is unreasonable to achieve this simply by depriving insurance managers of information they might need for the sound conduct of the business.

\section{ACKNOWLEDGEMENTS}

This work was carried out at the Genetics and Insurance Research Centre at Heriot-Watt University, which receives funding from a consortium of insurance companies through the Association of British Insurers. We thank the sponsors for funding, and members of the Steering Committee for helpful comments at various stages. We are grateful to Professor Peter Harper for his help.

\section{REFERENCES}

Brackenridge, R. \& Elder, J. (1998). Medical selection of life risks (fourth edition). Macmillan.

Brinkman, R., Mezei, M., Theilmann, J., Almqvist, E. \& Hayden, M. (1997). The likelihood of being affected with Huntington disease by a particular age, for a specific CAG size. American Journal of Human Genetics 60, 1202-1210.

Brock, D., Curtis, A., Barron, L., Dinwoodie, D., Crosbie, A., Mennie, M., Millan, F., Raeburn, J., Holloway, S. \& Wright, A. (1989). Predictive testing for Huntington's disease with linked DNA markers. The Lancet 2 (8661), 463-466.

Collett, D. (1994). Modelling survival data in medical research. London: Chapman \& Hall.

Dinani, A., Grimshaw D., Robjohns N., Somerville S., Spry A., Staffurth J. (2000). A critical review. Report of the Critical Illness Healthcare Study Group. Unpublished manuscript, The Staple Inn Actuarial Society.

Falush, D., Almqvist, E. W., Brinkmann, R. R., Iwasa, Y. \& Hayden, M. R. (2000). Measurement of mutational flow implies both a high new-mutation rate for Huntington disease and a substantial underascertainment of late-onset cases. American Journal of Human Genetics 68, 373-385.

Foroud, T., Gray, J., Ivashina, J. \& Conneally, M. (1999). Differences in duration of Huntington's disease based on age at onset. Journal of Neurology, Neurosurgery and Psychiatry 66, 52-56.

Gui, E. H. \& Macdonald, A. S. (2002). Early-onset Alzheimer's disease, critical illness insurance and life insurance. Research Report No. 02/2, Genetics and Insurance Research Centre, Heriot-Watt University, Edinburgh.

Gusella, J., Wexler, N., Conneally, M., Naylor, S., Anderson, M., Tanzi, R., Watkins, P., Ottina, K., Wallace, M., Sakaguchi, A., Young, A., Shoulson, I., Bonilla, E. \& Martin, J. (1983). A polymorphic DNA marker genetically linked to Huntington's disease. Nature 306, 234-238.

Gutiérrez, M. C. \& Macdonald, A. S. (2002). Huntington's disease and insurance I: A model of Huntington's disease. Research Report No. 02/3, Department of Actuarial Mathematics and Statistics, Heriot-Watt University. 
Gutiérrez, M. C. \& Macdonald, A. S. (2003). Adult polycystic kidney disease and critical illness insurance. North American Actuarial Journal 7(2), 93-115.

Harper, P. S. (1996). Huntington's Disease. W.B. Saunders.

Harper, P. S., Lim, C. \& Craufurd, D. (2000). Ten years of presymptomatic testing for Huntington's disease: the experience of the UK Huntington's Disease Prediction Consortium. Journal of Medical Genetics 37, 657-571.

Hoem, J. M. (1988). The versatility of the Markov chain as a tool in the mathematics of life insurance. Transactions of the 23rd International Congress of Actuaries, Helsinki S, 171-202.

Macdonald, A. S. (2003a). Moratoria on the use of genetic tests and family history for mortgage-related life insurance. To appear in British Actuarial Journal.

Macdonald, A. S. (2003b). Genetics and insurance: What have we learned so far? To appear in Scandinavian Actuarial Journal.

Macdonald, A. S., Waters, H. R. \& Wekwete, C. T. (2003a). The genetics of breast and ovarian cancer I: A model of family history. Scandinavian Actuarial Journal 2003, 1-27.

Macdonald, A. S., Waters, H. R. \& Wekwete, C. T. (2003b). The genetics of breast and ovarian cancer II: A model of critical illness insurance. Scandinavian Actuarial Journal 2003, $28-50$.

Meiser, B. \& Dunn, S. (2000). Psychological impact of genetic testing for Huntington's disease: an update of the literature. J. Neurol. Neurosurg. Psychiatry 69, 574-578.

Smith, C. (1998). Huntington's chorea: A mathematical model for life insurance. Unpublished manuscript, Swiss Re, Zurich.

Strachan, T. \& Read, S. (1999). Human molecular genetics (second edition). Bios Scientific Publishers Ltd, Oxford.

Wilkie, A. D. (2000). Report by the Independent Actuary on the Application by the Association of British Insurers to the Genetics and Insurance Committee for Approval to use Genetic Test Results for Insurance Risk Assessment - Use of Huntington's Disease Test in Life Insurance. Report available by request to the Genetics and Insurance Committee.

Manuscript accepted September 2, 2003

Address for correspondence:

Angus Macdonald

Department of Actuarial Mathematics and Statistics

Heriot-Watt University

Edinburgh EH14 4AS

U.K.

Tel: $+44(0) 131-451-3209$;

Fax: +44(0)131-451-3249

E-mail: A.S.Macdonald@ma.hw.ac.uk 